\title{
MicroRNA Deregulations in Head and Neck Squamous Cell Carcinomas
}

\author{
Dan Chen ${ }^{1,2}$, Robert J. Cabay ${ }^{3,4}$, Yi Jin ${ }^{1}$, Anxun Wang ${ }^{2}$, Yang Lu ${ }^{5,7}$, Muzaffar Shah-Khan ${ }^{1}$, Xiaofeng \\ Zhou ${ }^{1,6,7}$ \\ ${ }^{1}$ Center for Molecular Biology of Oral Diseases, College of Dentistry, University of Illinois at Chicago, Chicago, Illinois, \\ USA. \\ ${ }^{2}$ Department of Oral and Maxillofacial Surgery, First Affiliated Hospital, Sun Yat-sen University, Guangzhou, Guangdong, \\ China. \\ ${ }^{3}$ Department of Pathology, College of Medicine, University of Illinois at Chicago, Chicago, Illinois, USA. \\ ${ }^{4}$ Department of Oral Medicine and Diagnostic Sciences, College of Dentistry, University of Illinois at Chicago, Chicago, \\ Illinois, USA. \\ ${ }^{5}$ Section of Nuclear Medicine, Department of Radiology, University of Illinois at Chicago, Chicago, Illinois, USA. \\ ${ }^{6}$ Department of Periodontics, College of Dentistry, University of Illinois at Chicago, Chicago, Illinois, USA. \\ ${ }^{7}$ UIC Cancer Center, Graduate College, University of Illinois at Chicago, Chicago, Illinois, USA.
}

\author{
Corresponding Author: \\ Xiaofeng Zhou \\ College of Dentistry, University of Illinois at Chicago \\ 801 South Paulina Street, Chicago, IL 60612 \\ USA \\ Phone: $312-355-0825$ \\ Fax: 312-413-1604 \\ E-mail: xfzhou@uic.edu
}

\begin{abstract}
Objectives: Head and neck/oral cancer, predominantly head and neck squamous cell carcinoma (HNSCC), is the sixth most common cancer in the world. While substantial advances have been made to define the genomic alterations associated with head and neck/oral cancer, most studies are focused on protein coding genes. The aim of this article is to review the current literature on identified genomic aberrations of non-coding genes (e.g., microRNA) in head and neck/oral cancer (HNOC), and their contribution to the initiation and progression of HNOC.

Material and Methods: A comprehensive review of the available literature relevant to microRNA deregulation in HNSCC/HNOC, was undertaken using PubMed, Medline, Scholar Google and Scopus. Keywords for the search were: microRNA and oral cancer, microRNA and squamous cell carcinoma, microRNA deregulation and oral cancer, microRNA and carcinogenesis in the head and neck/oral cavity. Only full length articles in the English language were included.

Results: We recently identified a panel of microRNA deregulations that were consistently observed in HNSCC [Chen et al., Oral Oncol. 2012;48(8):686-91], including 7 consistently up-regulated microRNAs (miR-21, miR-7, miR-155, miR-130b, miR-223, miR-34b), and 4 consistently down-regulated microRNAs (miR-100, miR-99a, miR-125b, miR-375). In this review, we will first provide an overview on microRNA and HNSCC. We will then provide a comprehensive review on the roles of microRNA deregulations in HNSCC. The functional significance of the identified HNSCC-associated microRNAs and a number of other relevant microRNAs (e.g., miR-138, miR-98, miR-137, miR-193a and miR-218) will be discussed in detail. Conclusions: Based on current literature, microRNA deregulation plays a major role in head and neck/oral cancer.
\end{abstract}

Keywords: squamous cell carcinoma of the head and neck; microRNA; carcinogenesis tests.

Accepted for publication: 4 March 2013

To cite this article:

Chen D, Cabay RJ, Jin Y, Wang A, Luo Y, Shah-Khan M, Zhou X. MicroRNA Deregulations in Head and Neck Squamous Cell Carcinomas.

URL: http://www.ejomr.org/JOMR/archives/2013/1/e2/v4n1e2ht.pdf doi: $10.5037 /$ jomr.2013.4102 


\section{INTRODUCTION}

\section{Head and neck squamous cell carcinoma (HNSCC)}

Head and neck cancer, predominantly head and neck squamous cell carcinoma (HNSCC), is the sixth most common cancer, with a mortality rate of approximately $50 \%$. In the United States, while overall new cancer cases increased about $10 \%$ during the past 5 years, the new cases for oral cancer increased about $15 \%$. New cases for SCC of the tongue (one of the most frequent oral cancers) increased over $23 \%$ in the same period (Table 1). More strikingly, while deaths associated with all cancers increased slightly (2\%), the deaths associated with oral cancer increased by over $4 \%$. The number of deaths associated with tongue SCC has increased about $11 \%$ during the past 5 years [1-5]. Worldwide the problem is even worse, with over 263,000 new cases being diagnosed each year. In some parts of the world, such as South-Central Asia, home to one fifth of the world's population, oral cancer is a major health problem (the $2^{\text {nd }}$ most common cancer and $2^{\text {nd }}$ leading cause of cancer death in males in South-Central Asia, Global Cancer Facts \& Figures, $2^{\text {nd }}$ Edition; ACS, 2011). As an invasive epithelial neoplasm, HNSCC most commonly arises in the tongue, floor of the mouth, gingiva, buccal mucosa and pharynx. It typically presents as a painless ulcer with raised borders, firm mass or indurated nodule, and may show early and extensive lymph node metastases. The stages (tumour, node and metastasis, TNM) of HNSCC at diagnosis have an important influence on survival and prognosis. Lymph node metastasis decreases the survival rate by about $50 \%$ [6]. Known risk factors for HNSCC include tobacco smoking, smokeless tobacco use, alcohol consumption, and/or inflammation [7]. As a primary factor in the aetiology of HNSCC, the intensity and duration of tobacco consumption is directly correlated with the risk of developing HNSCC. Results from recent molecular and epidemiologic studies suggest that human papillomavirus (HPV) is also an important aetiologic factor in a subset of HNSCC [ $\underline{8}$ ], particularly those that develop in the pharynx, such as oropharyngeal and tonsillar cancers. In fact, HPV is implicated in the increased incidence of HNSCC in many areas of the world over the last few decades [911]. In the United States, the incidence of HPV-negative HNSCC declined by about 50\% from 1988 to 2004, while the incidence of HPV-positive HNSCC increased by over $200 \%$ during the same period. Most impacted by this increase were young individuals, Caucasian individuals, and men [11], which happen to be the same groups of individuals that are associated with a higher percentage of oral HPV infection in the United States [12].

As with other cancers, treatment for HNSCC often utilizes a multimodality approach and usually includes surgery, often a radical en bloc resection of the tumour, lymph nodes, and involved soft tissue and bone, combined with pre- and/or post-operative chemotherapy and radiotherapy, depending on clinical judgment and histopathological results. Despite these interventions, more than $50 \%$ of patients with HNSCC will experience local relapse and distant metastasis. Recurrences and distant metastases are associated with poorer prognoses [13]. Furthermore, surgical intervention causes facial contour defects and can lead to functional impairment and psychological trauma in HNSCC patients. This is disappointing and points to the need for novel therapeutic approaches. Tumourigenesis has proven to be a multigene and multi-step process; as an emerging mode of treatment, gene therapy may provide aid in the battle with this disease. As an etiologically-based therapeutic modality, gene therapy-based approach continues to grow more promising in the treatment of tumours

Table 1. Changes in oral cancer incidence and death (2007 - 2011)

\begin{tabular}{cccccccc}
\hline \multirow{2}{*}{ Year } & \multicolumn{3}{c}{ New Cases } & \multicolumn{3}{c}{ Deaths } \\
\cline { 2 - 7 } & All cancers & Oral cancer & Tongue cancer & All cancers & Oral cancer & Tongue cancer \\
\hline $\mathbf{2 0 0 7}$ & $1,444,920$ & 34,360 & 9,800 & 559,650 & 7,550 & 1,830 \\
\hline $\mathbf{2 0 0 8}$ & $1,437,180$ & 35,310 & 10,140 & 565,650 & 7,590 & 1,880 \\
\hline $\mathbf{2 0 0 9}$ & $1,479,350$ & 35,720 & 10,530 & 562,340 & 7,600 & 1,910 \\
\hline $\mathbf{2 0 1 0}$ & $1,529,560$ & 36,540 & 10,990 & 569,490 & 7,880 & 1,990 \\
\hline $\mathbf{2 0 1 1}$ & $1,596,670$ & 39,400 & 12,060 & 571,950 & 7,900 & 2,030 \\
\hline Total (2007 - 2011) & $7,487,680$ & 181,330 & 53,520 & $2,829,080$ & 38,520 & 9,640 \\
\hline 5-year increase & 151,750 & 5,040 & 2,260 & 12,300 & 350 & 200 & $\mathbf{4 . 6 \%}$ \\
\hline \% increase & $10.5 \%$ & $\mathbf{1 4 . 7 \%}$ & $\mathbf{2 3 . 1 \%}$ & $2.2 \%$ & $\mathbf{1 0 . 9 \%}$ \\
\hline
\end{tabular}

${ }^{a}$ The number of new cancer cases and deaths is based on the cancer statistics compiled by American Cancer Society from year 2007 to year $2011[\underline{1-5}]$. 
as the understanding of molecular pathogenicity expands.

\section{MicroRNA biology}

The microRNA field has experienced a major explosion in recent years. The microRNA gene family is continuously growing with novel members discovered in association with rapid advances in genomic technologies. It was previously predicted in 2005 that the human genome contains about 1000 microRNA genes [14]. As of today, there are 2,042 known mature microRNA species in human in miRBase (version 19). MicroRNAs are 21 to 23 nucleotide single stranded RNA molecules found in eukaryotic cells. MicroRNAs regulate the expression of over $50 \%$ of human genes at the post-transcriptional level guided by partial complementarities to specific sequences in their target messenger RNAs [15]. Each microRNA can target many mRNA transcripts and regulate hundreds of genes downstream. One microRNA can have multiple target sites in the mRNA transcript of a downstream gene.
Therefore, microRNAs contribute a newly recognized level of gene expression regulation. The microRNAmediated post-transcriptional regulation of gene expression is achieved through several mechanisms, including (1) site-specific cleavage; (2) enhanced mRNA degradation; and (3) translational inhibition [16]. MicroRNAs are involved in many essential biological activities such as cellular differentiation, proliferation, apoptosis and the cell cycle. Since the first evidence revealed the relationship between down-regulation of miR-15a, miR-16-1 and chronic lymphoid leukaemia (CLL) in 2002 [17], deregulations of microRNA have been reported in various types of cancers, and have been demonstrated to play crucial roles in the initiation and progression of tumours $[18,19]$. It is logical to hypothesize that microRNA alterations associated with tumours (including HNSCC) may serve as biomarkers for early diagnose, prognosis, evaluating treatment and monitoring the recurrence of cancers, and also serve as targets for novel therapeutic strategies. Here, we will summarize the current progress on microRNA studies in HNSCC and provide potential application perspectives.

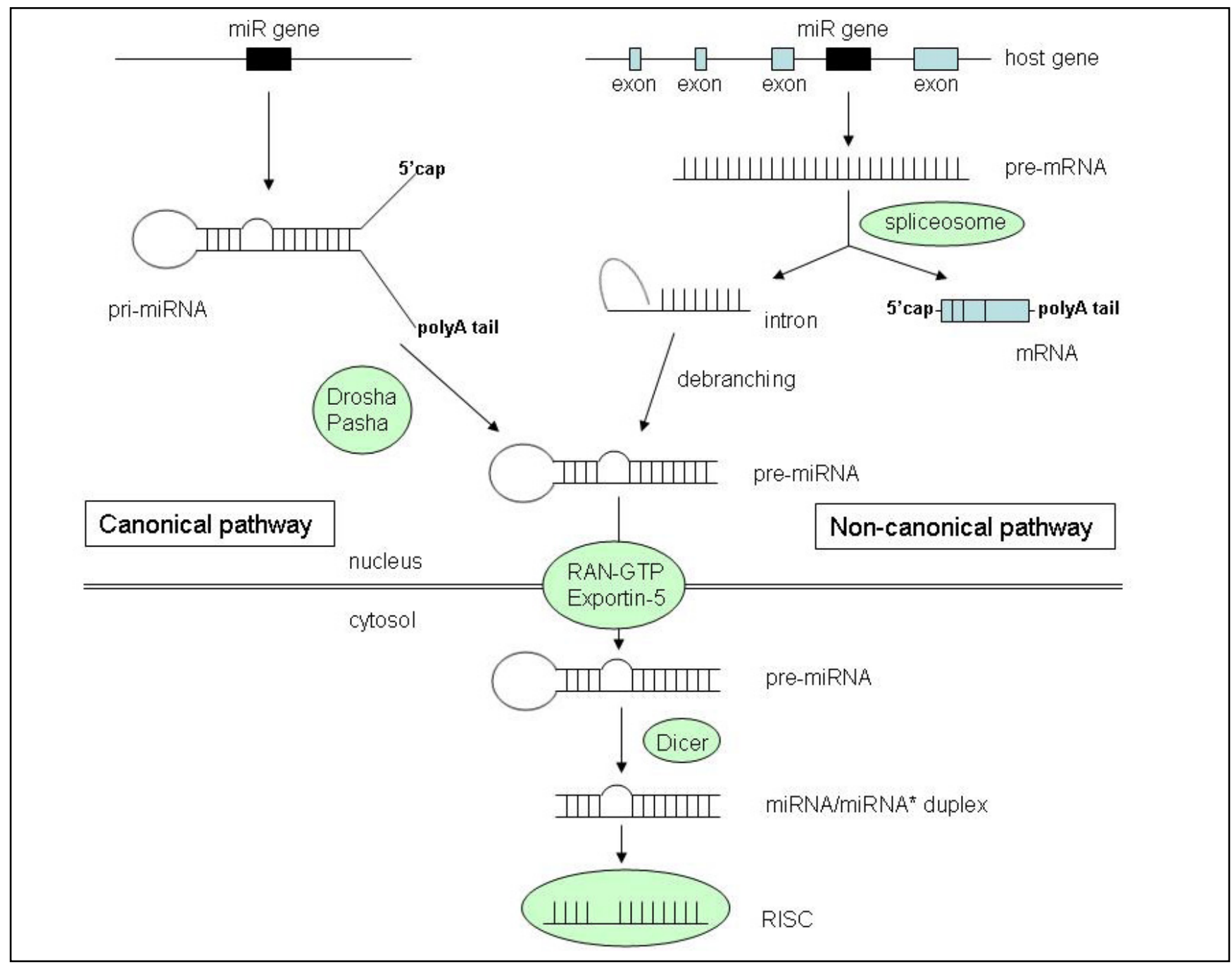

Figure 1. MicroRNA biogenesis (modified from Dai and Zhou, Open Access Bioinformatics 2010;2:29-39). 
Two microRNA biogenesis pathways have been described (Figure 1). A majority of the microRNA genes are intergenic and utilize a canonical microRNA biogenesis pathway for their expression. MicroRNAs are first transcribed as primary transcripts (pri-miRNA) containing a local-hairpin structure, which also possess many characteristics of typical message RNAs (mRNA), such as a $5^{\prime}$ cap and a $3^{\prime}$ poly-A tail. Unlike the maturation of mRNA that occurs in the nucleus, the pri-miRNAs are processed into 70-nucleotide stem-loop structures (known as pre-miRNA) in the cell nucleus. In animal cells, this processing is performed by a protein complex consisting of the nuclease Drosha and the double-stranded RNA binding protein Pasha. The pre-microRNAs are then transported to the cytoplasm by Exportin-5 (Exp5; a member of the Ran transport receptor family). Once in the cytoplasm, pre-microRNAs are further cleaved by Dicer (a second RNase III endonuclease) to form a short double stranded microRNA:microRNA* duplex. Finally, the microRNA:microRNA* duplex is unwound into mature microRNA and microRNA* by a helicase. The mature microRNAs are then incorporated into the RNA-induced silencing complex (RISC). RISC, also known as a microRNA ribonucleoprotein complex (miRNP), is responsible for the RNA-dependent gene silencing process (i.e., RNA interference) which is initiated by both microRNA and small interfering RNA (siRNA). The biogenesis pathway is different for microRNAs derived from intronic stem-loops which are processed by Dicer. No Drosha activity is needed for their maturation. For detailed discussion on microRNA biogenesis, we refer you to earlier reviews $[\underline{20}, \underline{21}]$.

\section{MATERIAL AND METHODS}

A comprehensive review of the available literature relevant to microRNA deregulation in HNSCC/HNOC was undertaken using PubMed, Medline, Scholar Google and Scopus. Keywords for the search were: microRNA and oral cancer, microRNA and squamous cell carcinoma, microRNA deregulation and oral cancer, microRNA and carcinogenesis in the head and neck/oral cavity. Only full length articles in the English language were included.

\section{RESULTS \\ MicroRNAs deregulation in HNSCC}

While the first microRNA, lin-4, was characterized in C. elegans in the early 1990s [22], it was not until 2000 that researchers knew that microRNAs existed in humans. In the early years, investigators mainly relied on 3 basic biochemical methods for the detection of microRNAs, including hybridization based methods (e.g., Northern blots), PCR-based detection, and cloning methods. However, the short length and uniqueness of each microRNA rendered many conventional methods ineffective; very small RNAs are difficult to reliably amplify or label without introducing bias.

Recent advances in high-throughput genomic profiling technologies (e.g., microarray, deep sequencing) led to a number of studies that attempted to define comprehensive microRNA profiles of various cancer types, including HNSCC. However, one of the bottlenecks in microRNA profiling is that there tends to be poor agreement among these profiling studies. Numerous potential factors may affect the observed inconsistencies such as heterogeneity in tissue samples, variations in genetic and environmental backgrounds of subjects, and differences in profiling technologies [23]. Although reanalysis of profiling data as a whole remains a challenge, meta-analysis of multiple studies is a reasonable approach for identifying consistentlyreported, differentially-expressed microRNAs in malignances. We recently performed a meta-analysis based on 13 independent microRNA profiling studies on HNSCC [24]. Among the 432 differentially expressed microRNAs reported in these studies, 90 were reported by at least 2 studies; of those 90 microRNAs, 67 (74.4\%) demonstrated a consistent direction of change, and 23 $(25.6 \%)$ with an inconsistent direction. Among the 67 microRNAs with consistent directions, 46 (68.7\%) were reported to be up-regulated, and $21(31.3 \%)$ were reported to be down-regulated. There were 11 differentially expressed microRNAs reported in at least four studies with consistent direction, including seven consistently up-regulated microRNAs (miR-21, miR7, miR-155, miR-130b, miR-31, miR-223, miR-34b), and four consistently down-regulated microRNAs (miR-100, miR-99a, miR-125b, miR-375) in HNSCC (Table 2).

\section{Functional relevance of the deregulated microRNAs in HNSCC}

Up- or down-regulation of microRNAs observed in tumours are not necessarily indicative of a causative role in tumourigenesis. It may be a secondary event as the consequence of the loss of normal cellular identity through malignant transformation. Thus, as Castoldi [25] proposed, to define the function of a microRNA as tumour suppressor or oncogene, four types of evidence must be provided: (1) data demonstrating widespread deregulation in diverse cancers, (2) gain or loss of microRNA function in tumours owing to deletion, 
Table 2. Differentially expressed microRNAs that were consistently reported in HNSCC (by at least 4 independent studies) (adopted from Chen et al., Oral Oncol. 2012;48(8):686-91)

\begin{tabular}{|c|c|c|c|c|c|c|}
\hline MicroRNA & $\begin{array}{c}\text { Chromosomal } \\
\text { location }\end{array}$ & Mature miR sequence & $\begin{array}{l}\text { Up-/down- } \\
\text { regulation }\end{array}$ & References & $\begin{array}{l}\text { No. of } \\
\text { reports }\end{array}$ & $\begin{array}{r}\text { Sample size } \\
\text { (SCC/ctrl) }\end{array}$ \\
\hline $\operatorname{miR}-21$ & $17 \mathrm{q} 23.1$ & uagcuuaucagacugauguuga & Up & {$[\underline{25-35}]$} & 11 & $192 / 112$ \\
\hline miR-155 & $21 \mathrm{q} 21.3$ & uuaaugcuaaucgugauaggggu & $\mathrm{Up}$ & {$[\underline{26}, \underline{28}, \underline{30}, \underline{32}, \underline{34}, \underline{35}]$} & 6 & $133 / 68$ \\
\hline $\mathrm{miR}-130 \mathrm{~b}$ & 22 & cagugcaaugaugaaagggcau & Up & {$[\underline{28}, \underline{30}, \underline{33}, \underline{34}]$} & 4 & $129 / 58$ \\
\hline miR-223 & $\mathrm{Xq12}$ & ugucaguuugucaaauacccca & Up & {$[\underline{28}, \underline{30}, \underline{34}, \underline{35}]$} & 4 & $125 / 60$ \\
\hline miR-31 & $9 \mathrm{p} 21.3$ & aggcaagaugcuggcauagcu & Up & {$[\underline{25,26,28,34]}$} & 4 & $73 / 63$ \\
\hline $\operatorname{miR}-7$ & $\begin{array}{c}9 \mathrm{q} 21.32 \text { or } \\
15 \mathrm{q} 26.1 \text { or } \\
19 \mathrm{p} 13.3\end{array}$ & uggaagacuagugauuuuguugu & Up & {$[\underline{29}, \underline{35}, \underline{102}, \underline{103}]$} & 4 & $48 / 30$ \\
\hline miR-34b & $11 \mathrm{q} 23.1$ & caaucacuaacuccacugccau & Up & {$[\underline{26}, \underline{28}, \underline{35}, \underline{103}]$} & 4 & $31 / 26$ \\
\hline miR-100 & $11 \mathrm{q} 24.1$ & aacccguagauccgaacuugug & Down & {$[\underline{26}, \underline{28-30}, \underline{34}]$} & 5 & $127 / 67$ \\
\hline miR-99a & $21 \mathrm{q} 21.1$ & aacccguagauccgaucuugug & Down & {$[\underline{26}, \underline{28-30}, \underline{34}]$} & 5 & $127 / 67$ \\
\hline miR-375 & $2 \mathrm{q} 35$ & uuuguucguucggcucgcguga & Down & {$[\underline{29}, \underline{30}, \underline{33}, \underline{34}]$} & 4 & $129 / 58$ \\
\hline $\operatorname{miR}-125 b$ & $11 \mathrm{q} 24.1$ or $21 \mathrm{q} 21.1$ & ucccugagacccuaacuuguga & Down & {$[\underline{26}, \underline{29}, \underline{30}, \underline{34]}$} & 4 & $117 / 57$ \\
\hline
\end{tabular}

amplification or mutation, (3) direct documentation of tumour-suppressing or tumour-promoting activity using animal models and (4) identification and verification of cancer-relevant targets that illuminate mechanisms through which the microRNAparticipates in oncogenesis. MicroRNA expression patterns are highly specific to different cell-type and cellular differentiation status. A number of microRNAs have been reported to be up-regulated in one type of cancer but downregulated in other cancers. For some microRNAs, both up- and down-regulation have been reported in the same cancer type by different studies. As such, they can not simply be defined as "oncomiR" or "tumour suppressor" without considering their molecular functions and their specific roles in malignancies.

The human gene for miR-21 is located on the plus strand of chromosome 17q23.2, within a coding gene transmembrane protein 49 (TMEM49). Despite being located in the intronic region of a coding gene in the direction of transcription, it has its own gene promoter which independently regulates the transcription of miR-21 gene. The up-regulation of miR-21 is the most frequently observed microRNA deregulation in HNSCC (reported in 11 out of 13 studies we surveyed [2636]), and in other cancer types including breast [37], ovary [38], cervix [39], colon [40], liver [41], brain [42] and esophagus [43]. MiR-21 is one of the most well-established oncogenic microRNAs. Significant association between miR-21 over-expression and poor prognosis of HNSCC patients has been reported recently $[26,44]$. Over-expression of miR-21 has also been observed in oral premalignancy lesions (leukoplakia), and the miR-21 expression was associated with increases in lesion severity during disease progression [36].
Results from a study by Hsu et al. [45] demonstrated that the miR-21 level in plasma was significantly higher in HNSCC patients as compared to normal control subjects. Furthermore, the plasma miR-21 level was also significantly reduced in the post-operative samples from the HNSCC patients as compared to the preoperative samples. As such, miR-21 may serve as a novel biomarker for both diagnosis and prognosis of HNSCC. A large number of target genes for miR-21 have been identified and experimentally confirmed, and most of them are established tumour suppressors (e.g., PTEN [41], PDCD4 [40], Tropomyosin [46], Sprouty 1 and 2 [47, 48], Bcl2 [49], RECK [ 50], JAG1 [51], HNRPK [46], TGFBRII [52], P12/CDK2AP1 [53], MEF2C [54], RhoB [ 55] ] and hMSH2 [ 56]), which supports the role of miR-21 as an oncomiR. A recent report by Zhang et al. [57] also suggested that miR-21 could affect formation of reactive oxygen species (ROS) by directly attenuating superoxide dismutase (SOD) family member 3, SOD3, and also by an indirect mechanism that limited TNF-a production, thereby reducing SOD2 levels to promote tumourigenesis.

MiR-155 has been suggested as an oncogene [58], and has been implicated in the regulation of cell survival, growth, and chemosensitivity [59-61]. Over-expression of the miR-155 gene has also be observed in several tumours, such as leukaemia and lymphoma $[\underline{62}, \underline{63}]$, thyroid carcinoma [64], breast cancer [37], cervical cancer [65], pancreatic cancer [666,67], lung cancer [68], and HNSCC $[\underline{27}, \underline{29}, \underline{31}, \underline{33}, \underline{35}, \underline{36}]$ and is associated with poor prognosis in patients with breast and lung cancers $[69,70]$. The expression of miR-155 is regulated by the TGF-beta/SMAD signaling pathway [59], which is frequently activated in HNSCC [71]. 
Functional studies revealed that miR-155 directly targets tumour protein 53-induced nuclear protein 1 (TP53INP1) and suppresses apoptosis in tumour cells $[72,73]$. Other experimentally confirmed target genes of miR-155 include: ARID2 (AT rich interactive domain 2), BACH1 (BTB and CNC homology 1), HIF (Hypoxia-inducible factor 1); receptors such as AT1R (Angiotensin II receptor, type 1) and CSF1R (Colony stimulating factor 1 receptor); kinases such as IKK2 (Inhibitor of kappa light polypeptide gene enhancer in B cells) and MAP3K7IP2 (Mitogen-activated protein kinase 7 interacting protein 2); and nuclear binding proteins such as AID (Activation-induced cytidine deaminase), JARID2 (Jumonji, AT rich interactive domain 2), PICALM (Phosphatidylinositol binding clathrin assembly protein), RHOA (Ras homolog gene family, member A) and SLA (Scr-like-adaptor) [74]. MiR-155 has also been shown to be involved in mammalian innate and adaptive immunity and viral infection $[\underline{75}, \underline{76}]$.

MiR-130b is consistently up-regulated in HNSCC $[29,31,34,35]$. In addition to HNSCC, miR-130b has also been shown to facilitate the growth and self-renewal of liver cancer-initiating cells [77], and to suppress the expression of tumour suppressor gene RUNX3 in gastric cancer [78]. The miR-130b signature may also serve as a potential prognostic marker for renal cell carcinoma patients [79]. Recent studies demonstrated that miR-130b also plays a role in regulating the senescence of keratinocytes and mammary epithelial cells $[\underline{80}, \underline{81}]$. Up-regulation of miR-130b has been suggested to contribute to human T-cell lymphotrophic virus 1 (HTLV-1)-mediated cellular transformation by targeting TP53INP1 and promoting cell proliferation and survival [82]. MiR-130a, another member of miR-130 family, was significantly down-regulated in Docetaxel induced multidrug cross-resistant HNSCC cell lines, and may contribute to multidrug resistance (MDR) [83].

MiR-223 was previously described as a haematopoietic specific microRNA, and it plays crucial role in myeloid lineage development $[\underline{84}, \underline{85}]$. The role of miR-223 in tumourigenesis appears to be cancer type specific. Reduced level of miR-223 is often observed in chronic lymphocytic leukaemia [86], acute lymphoblastic leukaemia [87], and acute myeloid leukaemia [ $[88,89]$. Enhanced expression of miR-223 is observed in several types of solid tumours, including esophageal cancer [90] and HNSCC $[29,31, \underline{35}, \underline{36}$. MiR-223 functions as an oncogene in gastric cancer, and promotes gastric cancer invasion and metastasis by targeting tumour suppressor genes F-box and WD40 domain protein 7 (FBXW7) and erythrocyte membrane protein band 4.1-like 3 (EPB41L3) [91,92]. Increases of miR-223 in serum may serve as a biomarker for hepatocellular cancer [93].

As shown in Table 2, up-regulation of miR-31 is frequently observed in HNSCC. Increases of miR-31 in plasma and saliva have also been suggested as a potential biomarker for early detection of OSCC [94]. However, the expression pattern of miR-31 appears to be cancer type specific. While up-regulation of miR31 has also been observed in colorectal cancer $[95,96]$ and hepatocellular carcinoma [97], reduced level of miR-31 has been observed in breast cancer [98], and frequent homozygous deletion of miR-31 gene has been reported in urothelial carcinomas [99]. The role of miR31 in tumourigenesis also appears to be cancer type (or cell type) specific. While miR-31 inhibits metastasis in breast cancer [100], up-regulation of miR-31 is essential to the TGF-beta-induced invasion and metastasis of colon cancer cells [101]. For pancreatic cancer, both inhibition and enhanced expression of miR-31 lead to reduced migration and invasion in different pancreatic cancer cell lines [102]. More studies will be needed to define the role of miR-31 in tumourigenesis.

The expression of miR-7 in cancer cells seems to vary depending on specific cell type or tissue type. While upregulation of miR-7 was reported in HNSCC by several studies $[\underline{30}, \underline{36}, \underline{103}, \underline{104}]$, down-regulation of miR-7 has been reported in other cancer types [105-107], and also reported in tongue SCC cell lines $[108,109]$. It is worth noting that there are $3 \mathrm{miR}-7$ genes in the human genome (located at 9q21.32, 15q26.1, and 19p13.3). The tissue specific- (or cell type specific-) differential expression of these 3 miR-7 genes may contribute to the observed variation in miR-7 level in different cancer types or tissue type. Additional that studies focus on individual miR-7 genes will be needed to address these apparent contradictions. MiR-7 has been suggested as a tumour suppressor based on its target genes, including several proto-oncogenes such as insulin receptor substrate 1 (IRS1), insulin receptor substrate 2 (IRS2), epidermoid growth factor receptor (EGFR), v-raf-1 murine leukaemia viral oncogene homolog 1 (RAF1) and p21/CDC42/RAC1-activated kinase 1 (PAK1) [105-107]. A study by Jiang et al. [110] in 2010 demonstrated that insulin-like growth factor 1 receptor (IGF1R) is a novel target of miR-7 in tongue SCC cell lines. They further demonstrated that miR7-mediated down-regulation of IGF1R attenuated the insulin growth factor 1 (IGF1)-induced activation of protein kinase $\mathrm{B}$, and lead to reduced cell proliferation, cell cycle arrest and an increase in apoptosis [110]. The potential oncogenetic role of miR-7 appears to be linked to differentiation, as miR-7 has been suggested as one of the keratinization-associated microRNAs in oral cancer [111]. A study by Jung et al. showed that miR-7 targets 
tumour suppressor gene reversion-inducing-cysteinerich protein with kazal motifs (RECK) in oral cancer, a key regulator of extracellular matrix integrity [111]. As such, miR-7 regulates multiple signalling pathways in a tissue specific (and/or differentiation status specific) manner, but its precise roles in tumourigenesis are still elusive.

The role of miR-34b appears to be tumour type specific. While miR-34b has been suggested as a tumour suppressor in colorectal [112], prostate [113], gastric [114] and breast cancer [115], up-regulation of miR-34b has been consistently reported in HNSCC $[27,29,36,104]$. Up-regulation of other members of the miR-34 family (e.g., miR-34c) has also been reported in tongue SCC [27]. MiR-34b is involved in a number of tumourigenesis-related molecular mechanisms, including epithelial-mesenchymal-transition (EMT) [116]. The gene for MiR-34b is located in a CpG islandrich region, and aberrant DNA methylation status of its promoter has been linked to decreased levels of MiR-34b. Several studies reported that miR-34b gene was silenced by DNA methylation in various cancers, including oral cancer [117], esophageal squamous cell carcinoma (ESCC) [118], and non-small cell lung cancer (NSCLC) [119]. The expression of miR-34b appears to be further controlled by $\mathrm{p} 53$ at the transcriptional level (e.g., regulating the gene promoter activity) [120122], and appears to be a critical component of the p53-regulatory network. MiR-34b has been showed to down-regulate Met, which subsequent controls its downstream signalling molecules (e.g., p53 and Mdm2). On the other hand, the p53-mediated upregulation of miR-34b provides a feedback loop in the p53-regulatory network [123].

MiR-99a and miR-100 are members of the miR-99 family (miR-99b is the $3^{\text {rd }}$ member of the miR-99 family). The miR-99 family is one of the evolutionarily most ancient microRNA families whose origin dates back before the bilaterian ancestor $[124,125]$. Deregulation of the miR-99 family members has been consistently reported in HNSCC and other cancer types [2ㄱ, 29-31, $\underline{35}$, 126-131]. Forced expression of miR-99 family members in HNSCC cell lines led to a reduction in cell proliferation and cell migration, and an increase in apoptosis [24]. A number of functional studies suggested that members of the miR-99 family regulate AKT/mTOR signalling pathways by targeting insulinlike growth factor 1 receptor (IGF1R), mechanistic target of rapamycin (mTOR) and regulatory associated protein of mTOR (Raptor) [133-136]. A recent study by Mueller et al. [137] also suggested that miR-99 family members regulate the DNA damage response through their target gene SWI/SNF chromatin remodelling factor (SMARCA5).
Reduction in miR-375 expression has been correlated with poor outcome and metastasis in oral squamous cell carcinoma (OSCC) [138]. MiR-375 may function as a tumour suppressor by suppressing the tumour's invasive properties in OSCC [138]. Frequent down-regulation of miR-375 has also been reported to be consistently repressed compared to adjacent matched normal tissues and healthy tissues in gastric, liver, and breast cancers and has been shown to inhibit cell proliferation and regulate cell survival [139-142]. Functional analysis revealed that miR-375 targets a panel of oncogenes including AEG-1/MTDH [143], lactate dehydrogenase B (LDHB) [132] and 3'-phosphoinositide-dependent protein kinase 1 (PDK1) [144].

The down-regulation of miR-125b appears to play an essential role in the initiation and progression of HNSCC [129,145], and may contribute to resistance to cellular ionizing radiation [129]. There are $2 \mathrm{miR}$ $125 \mathrm{~b}$ genes in the human genome (located at 11q24.1 or $21 \mathrm{q} 21.1)$. One of the genes for miR-125b is closely localized with the gene for miR-100 (11q24.1; one of the most frequently deleted genomic region in OSCC), and concurrent down-regulation of miR-125b and miR-100 is often observed in OSCC [129]. Forced expression of miR-125b down-regulated a number of differentiationand cell cycle-related genes (including KLF13, CXCL11 and FOXA1), and consequently reduced cell proliferation [129]. MiR-125b has also been suggested to play a role in other solid tumours. Studies by Shang el al. [146] showed that miR-125b was down-regulated in endometrioid endometrial cancers (EEC), and forced expression of miR-125b in an EEC cell line suppressed cancer cell invasion. Functional studies suggested that the observed inhibitory effect of miR-125b on EEC cell invasion was mediated in part by miR-125bmediated down-regulation of proto-oncogene ERBB2 [146]. MiR-125b has also been showed to suppress proliferation, colony formation, migratory, and invasive capacity of cutaneous squamous cell carcinoma cells [147]. Functional analysis by Xu et al. [147] showed that the observed tumour suppressive effects of miR$125 \mathrm{~b}$ were achieved in part by inhibiting the expression of matrix metallopeptidase 13 (MMP13) expression.

\section{Other functionally relevant microRNAs in HNSCC}

While high-throughput profiling studies based on comparing tumour and normal tissue samples led to the identification of some critical microRNA players in HNSCC, these cross-sectional studies inevitably missed a number of differentially expressed microRNAs, including microRNA alterations that are associated with disease progression (and/or specific stages). Down-regulation of miR-138 is an example of one such 
microRNA alteration. To identify microRNAs associated with HNSCC metastasis, Liu et al. [108] examined the differential expression of microRNAs in a panel of HNSCC cell lines with different metastatic potential. Their result showed that miR-138 is consistently downregulated in highly metastatic cell lines. Restoring miR138 led to suppression of cell invasion, cell cycle arrest and induced apoptosis. In contrast, knockdown of miR138 enhanced cell invasion and suppressed apoptosis. The fact that highly metastatic cells often showed reduced expression of miR-138 suggests the potential role of miR-138 as a metastatic suppressor, and may serve as a potential therapeutic target for HNSCC patients at risk of metastasis. The same group of investigators later validated the down-regulation of miR-138 in tongue SCC tissue samples [148], and down-regulation of miR-138 was also reported in HNSCC by different labs $[27,148,149]$. Recent functional analysis demonstrated that miR-138 regulates cell migration and invasion by concurrently targeting RhoC and ROCK2, leading to the down-regulation of the Rho GTPase signalling pathway that is essential for actin cytoskeleton remodelling [150]. Tumour cells can dedifferentiate through activation of specific biological pathways associated with epithelialmesenchymal-transition (EMT), thereby gaining the ability to migrate and invade. EMT is characterized by the loss of epithelial-cell markers (e.g., E-cadherin) and the gain of mesenchymal-cell markers (e.g., Vimentin). Previous studies suggested that members of the miR200 family regulate EMT by targeting the Zinc finger E-box-binding homeobox (ZEB) family of transcription repressors (ZEB1 and ZEB2) which control E-cadherin expression [151]. Furthermore, down-regulation of miR-101 leads to the overexpression of polycomb group protein EZH2 $[152,153]$, which also acts as a transcription suppressor to inhibit the expression of E-cadherin and induce EMT [154]. Both bioinformatics analysis and in vitro experimental results indicated that miR-138 targets ZEB and EZH repressors, and other molecular regulators that control E-cadherin expression, such as FOSL1. Interestingly, miR-138 also controls Vim expression by interacting with its targeting sequences located in both the 3'-UTR and coding region of the Vim gene. As such, these studies suggested that miR-138 is an essential EMT regulator that controls EMT through multiple pathways. Taken together, these observations suggest that miR-138 is a multi-functional molecular regulator, and the down-regulation of miR138 in HNSCC plays essential roles in the neoplastic progression of HNSCC in terms of enhancing the metastatic potential of the HNSCC cells by promoting EMT and enhancing cell migration and invasion.

The ability for the cancer cells to survive under hypoxic conditions or in the presence of chemotherapeutic drugs by developing resistance contributes significantly to treatment failures, and yet the molecular mechanism is still poorly understood. Recent evidence suggested that microRNA deregulation plays a role in these adaptations in cancer cells. The High Mobility Group A2 (HMGA2) protein has been showed to be regulated in part by miR98 in HNSCC cell lines under hypoxic conditions [155]. HMGA2 expression occurs predominately during embryogenesis, however, proteins from the HMGA family are implicated in differentiation, neoplastic transformation, and integration and expression of viral genomes. HMGA2 has been implicated in acquisition of mesenchymal characteristics by OSCC cells. It is worth noting that MiR-98 is a member of the let-7 family, one of the first microRNAs to be identified. Let- 7 has been shown to act as a master regulator for cell cycle exit [156].

Hypermethylation of DNA at CpG-islands is one of the most frequent epigenetic events that contributes to the silencing of many tumour-suppresser genes. MiR-137, miR-193a and miR-218 have been showed to be silenced by DNA hypermethylation in HNSCC $[117,157]$. DNA hypermethylation-based silencing of miR-137 has also been reported in glioblastoma [158]. The forced expression of miR-137 or miR-193a in a OSCC cell line led to significant down-regulation of cyclin-dependent kinase 6 or E2F transcription factor 6 , respectively, as well as reduced cell growth [117]. These observations are consistent with previous findings in which tumour suppressing roles have been suggested for miR-137 in glioblastoma [158] and melanoma [159], and for miR-193a in hepatocarcinoma, lung epithelial carcinoma and cervical adenocarcinoma cell lines [72]. The putative tumour suppression function of miR-218 in OSCC is linked to its effect on the expression of rapamycin-insensitive companion of mTOR (Rictor) and the phosphorylation of AKT [157].

\section{CONCLUSIONS}

MicroRNAs are pivotal regulators of diverse cellular processes including proliferation, differentiation, apoptosis, survival, motility and morphogenesis. While extensive literature exists on microRNAs and their involvement in tumourigenesis, the understanding of microRNA deregulation and its role in HNSCC is lagging behind. Recent advances in microRNA expression profiling have led to a better understanding of HNSCC pathogenesis. This information will lead to the identification of specific microRNA expression patterns that may become powerful biomarkers for the diagnosis and prognosis of HNSCC. In addition, the expanding knowledge of specific 
roles of certain microRNAs will further contribute to our understanding of the complexity of tumour progression and behaviour. Among the deregulated microRNAs, several (e.g., miR-21) have been functionally validated and their potential target genes have been indentified. Several other microRNAs known to be involved in tumourigenesis have been reported with conflicting findings; additional studies will be needed to fully explore their roles in HNSCC. Nevertheless, consideration of this information and incorporation into treatment modalities through targeted therapy could potentially enhance our abilities to improve outcomes especially when other established therapies have failed. It is important to note that HNSCC is a group of diverse cancers that develop from many different anatomical sites and are associated with different risk factors [160], genetic characteristics [161], and different clinical outcomes $[\underline{162}, \underline{163}]$. Currently, most of the existing microRNA profiling studies on HNSCC include cases from multiple anatomical sites. Ideally, site specific microRNA signatures for various HNSCC subtypes should be identified, which will lead to substantial translational outcomes that will advance the management of these HNSCC subtypes. This has been realized to some extent already, and a few studies have been devoted to the identification of site specific
microRNA signature for HNSCC, including a study by Lajer et al., [35], to identify microRNAs alterations associated specifically with HNSCCs of the oral cavity, and the HNSCCs of the oro- or hypopharynx. This apparent site specific microRNA pattern of HNSCC may also reflect the differences in etiologic factors of HNSCC (e.g., the classic tobacco/alcohol associate HNSCC vs. the HPV associated subset of HNSCC). Such advances in the understanding of HNSCC could help to devise more clinically appropriate and cost-effective therapeutic management strategies in a variety of health care settings. Enhancements to the characterization and treatment of HNSCC would add beneficial elements to a personalized medicine model that could prove helpful in maximizing disease-specific treatment options, minimizing collateral tissue damage, and allowing for improved outcomes for a greater number of patients.

\section{ACKNOWLEDGMENTS AND DISCLOSURE STATEMENTS}

This work was supported in part by NIH PHS grants (CA171436). Yi Jin is supported by a T32 training grant (DE018381). We thank Dr. Wendy Cerny for her editorial assistance.

\section{REFERENCES}

1. Siegel R, Ward E, Brawley O, Jemal A. Cancer statistics, 2011: the impact of eliminating socioeconomic and racial disparities on premature cancer deaths. CA Cancer J Clin. 2011 Jul-Aug;61(4):212-36. Epub 2011 Jun 17. [Medline: 21685461] [doi: 10.3322/caac.20121] [FREE Full Text]

2. Jemal A, Siegel R, Ward E, Murray T, Xu J, Thun MJ. Cancer statistics, 2007. CA Cancer J Clin. 2007 Jan-Feb;57(1):43-66. [Medline: 17237035 ] [doi: $10.3322 /$ canjclin.57.1.43] [FREE Full Text]

3. Jemal A, Siegel R, Ward E, Hao Y, Xu J, Murray T, Thun MJ. Cancer statistics, 2008. CA Cancer J Clin. 2008 MarApr;58(2):71-96. Epub 2008 Feb 20. [Medline: 18287387] [doi: 10.3322/CA.2007.0010] [FREE Full Text]

4. Jemal A, Siegel R, Ward E, Hao Y, Xu J, Thun MJ. Cancer statistics, 2009. CA Cancer J Clin. 2009 Jul-Aug;59(4):225-49. Epub 2009 May 27. [Medline: 19474385] [doi: 10.3322/caac.20006] [FREE Full Text]

5. Jemal A, Siegel R, Xu J, Ward E. Cancer statistics, 2010. CA Cancer J Clin. 2010 Sep-Oct;60(5):277-300. Epub 2010 Jul 7. Erratum in: CA Cancer J Clin. 2011 Mar-Apr;61(2):133-4. [Medline: 20610543] [doi: 10.3322/caac.20073] [FREE Full Text]

6. Kowalski LP, Bagietto R, Lara JR, Santos RL, Tagawa EK, Santos IR. Factors influencing contralateral lymph node metastasis from oral carcinoma. Head Neck. 1999 Mar;21(2):104-10. [Medline: 10091977] [10.1002/(SICI)1097-0347(199903)21:2<104::AID-HED2>3.0.CO;2-L]

7. Capote-Moreno A, Naval L, Muñoz-Guerra MF, Sastre J, Rodríguez-Campo FJ. Prognostic factors influencing contralateral neck lymph node metastases in oral and oropharyngeal carcinoma. J Oral Maxillofac Surg. 2010 Feb;68(2):268-75. [Medline: 20116694] [doi: 10.1016/j.joms.2009.09.071]

8. Herrero R, Castellsagué X, Pawlita M, Lissowska J, Kee F, Balaram P, Rajkumar T, Sridhar H, Rose B, Pintos J, Fernández L, Idris A, Sánchez MJ, Nieto A, Talamini R, Tavani A, Bosch FX, Reidel U, Snijders PJ, Meijer CJ, Viscidi R, Muñoz N, Franceschi S; IARC Multicenter Oral Cancer Study Group. Human papillomavirus and oral cancer: the International Agency for Research on Cancer multicenter study. J Natl Cancer Inst. 2003 Dec 3;95(23):1772-83. [Medline: 14652239] [doi: 10.1093/jnci/dig107] [FREE Full Text]

9. Näsman A, Attner P, Hammarstedt L, Du J, Eriksson M, Giraud G, Ahrlund-Richter S, Marklund L, Romanitan M, Lindquist D, Ramqvist T, Lindholm J, Sparén P, Ye W, Dahlstrand H, Munck-Wikland E, Dalianis T. Incidence of human papillomavirus (HPV) positive tonsillar carcinoma in Stockholm, Sweden: an epidemic of viral-induced carcinoma? Int J Cancer. 2009 Jul 15;125(2):362-6. [Medline: 19330833] [doi: 10.1002/ijc.24339] 
10. Hong AM, Grulich AE, Jones D, Lee CS, Garland SM, Dobbins TA, Clark JR, Harnett GB, Milross CG, O’Brien CJ, Rose BR. Squamous cell carcinoma of the oropharynx in Australian males induced by human papillomavirus vaccine targets. Vaccine. 2010 Apr 26;28(19):3269-72. Epub 2010 Mar 10. [Medline: 20226244] [doi: 10.1016/j.vaccine.2010.02.098]

11. Chaturvedi AK, Engels EA, Pfeiffer RM, Hernandez BY, Xiao W, Kim E, Jiang B, Goodman MT, Sibug-Saber M, Cozen W, Liu L, Lynch CF, Wentzensen N, Jordan RC, Altekruse S, Anderson WF, Rosenberg PS, Gillison ML. Human papillomavirus and rising oropharyngeal cancer incidence in the United States. J Clin Oncol. 2011 Nov 10;29(32):4294301. Epub 2011 Oct 3. [Medline: 21969503] [doi: 10.1200/JCO.2011.36.4596] [FREE Full Text]

12. Gillison ML, Broutian T, Pickard RK, Tong ZY, Xiao W, Kahle L, Graubard BI, Chaturvedi AK. Prevalence of oral HPV infection in the United States, 2009-2010. JAMA. 2012 Feb 15;307(7):693-703. Epub 2012 Jan 26. [Medline: 22282321] [doi: 10.1001/jama.2012.101]

13. Khuri FR, Shin DM, Glisson BS, Lippman SM, Hong WK. Treatment of patients with recurrent or metastatic squamous cell carcinoma of the head and neck: current status and future directions. Semin Oncol. 2000 Aug;27(4 Suppl 8):25-33. [Medline: 10952435]

14. Bentwich I, Avniel A, Karov Y, Aharonov R, Gilad S, Barad O, Barzilai A, Einat P, Einav U, Meiri E, Sharon E, Spector Y, Bentwich Z. Identification of hundreds of conserved and nonconserved human microRNAs. Nat Genet. 2005 Jul;37(7):766-70. Epub 2005 Jun 19. [Medline: 15965474] [doi: 10.1038/ng1590]

15. Friedman RC, Farh KK, Burge CB, Bartel DP. Most mammalian mRNAs are conserved targets of microRNAs. Genome Res. 2009 Jan;19(1):92-105. Epub 2008 Oct 27. [Medline: 18955434] [FREE Full Text] [doi: 10.1101/gr.082701.108]

16. Iorio MV, Croce CM. MicroRNA dysregulation in cancer: diagnostics, monitoring and therapeutics. A comprehensive review. EMBO Mol Med. 2012 Mar;4(3):143-59. Epub 2012 Feb 20. Review. [Medline: 22351564] [FREE Full Text] [doi: 10.1002/emmm.201100209]

17. Calin GA, Dumitru CD, Shimizu M, Bichi R, Zupo S, Noch E, Aldler H, Rattan S, Keating M, Rai K, Rassenti L, Kipps T, Negrini M, Bullrich F, Croce CM. Frequent deletions and down-regulation of micro- RNA genes miR15 and miR16 at 13 q14 in chronic lymphocytic leukemia. Proc Natl Acad Sci U S A. 2002 Nov 26;99(24):15524-9. Epub 2002 Nov 14. [Medline: 12434020] [doi: 10.1073/pnas.242606799] [FREE Full Text]

18. Calin GA, Croce CM. MicroRNA signatures in human cancers. Nat Rev Cancer. 2006 Nov;6(11):857-66. Review. [Medline: 17060945] [doi: 10.1038/nrc1997]

19. Volinia S, Calin GA, Liu CG, Ambs S, Cimmino A, Petrocca F, Visone R, Iorio M, Roldo C, Ferracin M, Prueitt RL, Yanaihara N, Lanza G, Scarpa A, Vecchione A, Negrini M, Harris CC, Croce CM. A microRNA expression signature of human solid tumors defines cancer gene targets. Proc Natl Acad Sci U S A. 2006 Feb 14;103(7):2257-61. Epub 2006 Feb 3. [Medline: 16461460] [doi: 10.1073/pnas.0510565103] [FREE Full Text]

20. Bartel DP. MicroRNAs: genomics, biogenesis, mechanism, and function. Cell. 2004 Jan 23;116(2):281-97. Review. [Medline: 14744438] [doi: 10.1016/S0092-8674(04)00045-5]

21. Carthew RW, Sontheimer EJ. Origins and Mechanisms of miRNAs and siRNAs. Cell. 2009 Feb 20;136(4):642-55. Review. [Medline: 19239886] [doi: 10.1016/j.cell.2009.01.035] [FREE Full Text]

22. Lee RC, Feinbaum RL, Ambros V. The C. elegans heterochronic gene lin-4 encodes small RNAs with antisense complementarity to lin-14. Cell. 1993 Dec 3;75(5):843-54. [Medline: 8252621] [doi: 10.1016/0092-8674(93)90529-Y]

23. Gandellini P, Folini M, Zaffaroni N. Towards the definition of prostate cancer-related microRNAs: where are we now? Trends Mol Med. 2009 Sep;15(9):381-90. Epub 2009 Aug 27. [Medline: 19716766] [doi: 10.1016/j.molmed.2009.07.004]

24. Chen Z, Jin Y, Yu D, Wang A, Mahjabeen I, Wang C, Liu X, Zhou X. Down-regulation of the microRNA-99 family members in head and neck squamous cell carcinoma. Oral Oncol. 2012 Aug;48(8):686-91. Epub 2012 Mar 17. [Medline: 22425712] [doi: 10.1016/j.oraloncology.2012.02.020] [FREE Full Text]

25. Castoldi M, Schmidt S, Benes V, Noerholm M, Kulozik AE, Hentze MW, Muckenthaler MU. A sensitive array for microRNA expression profiling (miChip) based on locked nucleic acids (LNA). RNA. 2006 May;12(5):913-20. Epub 2006 Mar 15. [Medline: 16540696] [doi: 10.1261/rna.2332406] [FREE Full Text]

26. Li J, Huang H, Sun L, Yang M, Pan C, Chen W, Wu D, Lin Z, Zeng C, Yao Y, Zhang P, Song E. MiR-21 indicates poor prognosis in tongue squamous cell carcinomas as an apoptosis inhibitor. Clin Cancer Res. 2009 Jun 15;15(12):3998-4008. Epub 2009 Jun 9. [Medline: 19509158] [doi: 10.1158/1078-0432.CCR-08-3053] [FREE Full Text]

27. Wong TS, Liu XB, Wong BY, Ng RW, Yuen AP, Wei WI. Mature miR-184 as Potential Oncogenic microRNA of Squamous Cell Carcinoma of Tongue. Clin Cancer Res. 2008 May 1;14(9):2588-92 [Medline: 18451220] [doi: 10.1158/1078-0432.CCR-07-0666] [FREE Full Text]

28. Scapoli L, Palmieri A, Lo Muzio L, Pezzetti F, Rubini C, Girardi A, Farinella F, Mazzotta M, Carinci F. MicroRNA expression profiling of oral carcinoma identifies new markers of tumor progression. Int J Immunopathol Pharmacol. 2010 Oct-Dec;23(4):1229-34. [Medline: 21244772]

29. Liu CJ, Tsai MM, Hung PS, Kao SY, Liu TY, Wu KJ, Chiou SH, Lin SC, Chang KW. miR-31 ablates expression of the HIF regulatory factor FIH to activate the HIF pathway in head and neck carcinoma. Cancer Res. 2010 Feb 15;70(4):163544. Epub 2010 Feb 9. [Medline: 20145132] [doi: 10.1158/0008-5472.CAN-09-2291] [FREE Full Text]

30. Kikkawa N, Hanazawa T, Fujimura L, Nohata N, Suzuki H, Chazono H, Sakurai D, Horiguchi S, Okamoto Y, Seki N. miR-489 is a tumour-suppressive miRNA target PTPN11 in hypopharyngeal squamous cell carcinoma (HSCC). Br J Cancer. 2010 Sep 7;103(6):877-84. Epub 2010 Aug 10. [Medline: 20700123] [doi: 10.1038/sj.bjc.6605811] [FREE Full Text]

31. Hui AB, Lenarduzzi M, Krushel T, Waldron L, Pintilie M, Shi W, Perez-Ordonez B, Jurisica I, O’Sullivan B, Waldron J, Gullane P, Cummings B, Liu FF. Comprehensive MicroRNA profiling for head and neck squamous cell carcinomas. Clin Cancer Res. 2010 Feb 15;16(4):1129-39. Epub 2010 Feb 9. [Medline: 20145181] [doi: 10.1158/1078-0432.CCR-09-2166] [FREE Full Text] 
32. Childs G, Fazzari M, Kung G, Kawachi N, Brandwein-Gensler M, McLemore M, Chen Q, Burk RD, Smith RV, Prystowsky MB, Belbin TJ, Schlecht NF. Low-level expression of microRNAs let-7d and miR-205 are prognostic markers of head and neck squamous cell carcinoma. Am J Pathol. 2009 Mar;174(3):736-45. Epub 2009 Jan 29. [Medline: 19179615] [doi: 10.2353/ajpath.2009.080731] [FREE Full Text]

33. Chang SS, Jiang WW, Smith I, Poeta LM, Begum S, Glazer C, Shan S, Westra W, Sidransky D, Califano JA. MicroRNA alterations in head and neck squamous cell carcinoma. Int J Cancer. 2008 Dec 15;123(12):2791-7. [Medline: 18798260] [doi: 10.1002/ijc.23831] [FREE Full Text]

34. Avissar M, Christensen BC, Kelsey KT, Marsit CJ. MicroRNA expression ratio is predictive of head and neck squamous cell carcinoma. Clin Cancer Res. 2009 Apr 15;15(8):2850-5. Epub 2009 Apr 7. [Medline: 19351747] [doi: 10.1158/1078-0432.CCR-08-3131] [FREE Full Text]

35. Lajer CB, Nielsen FC, Friis-Hansen L, Norrild B, Borup R, Garnæs E, Rossing M, Specht L, Therkildsen MH, Nauntofte B, Dabelsteen S, von Buchwald C. Different miRNA signatures of oral and pharyngeal squamous cell carcinomas: a prospective translational study. Br J Cancer. 2011 Mar 1;104(5):830-40. Epub 2011 Feb 15. [Medline: 21326242] [doi: 10.1038/bjc.2011.29] [ [FREE Full Text]

36. Cervigne NK, Reis PP, Machado J, Sadikovic B, Bradley G, Galloni NN, Pintilie M, Jurisica I, Perez-Ordonez B, Gilbert R, Gullane P, Irish J, Kamel-Reid S. Identification of a microRNA signature associated with progression of leukoplakia to oral carcinoma. Hum Mol Genet. 2009 Dec 15;18(24):4818-29. Epub 2009 Sep 23. [Medline: 19776030] [doi: $10.1093 / \mathrm{hmg} / \mathrm{ddp} 446]$ [FREE Full Text]

37. Iorio MV, Ferracin M, Liu CG, Veronese A, Spizzo R, Sabbioni S, Magri E, Pedriali M, Fabbri M, Campiglio M, Ménard S, Palazzo JP, Rosenberg A, Musiani P, Volinia S, Nenci I, Calin GA, Querzoli P, Negrini M, Croce CM. MicroRNA gene expression deregulation in human breast cancer. Cancer Res. 2005 Aug 15;65(16):7065-70. [Medline: 16103053] [doi: 10.1158/0008-5472.CAN-05-1783] [ [FREE Full Text]

38. Iorio MV, Visone R, Di Leva G, Donati V, Petrocca F, Casalini P, Taccioli C, Volinia S, Liu CG, Alder H, Calin GA, Ménard S, Croce CM. MicroRNA signatures in human ovarian cancer. Cancer Res. 2007 Sep 15;67(18):8699-707. [Medline: 17875710] [doi: 10.1158/0008-5472.CAN-07-1936] [FREE Full Text]

39. Lui WO, Pourmand N, Patterson BK, Fire A. Patterns of known and novel small RNAs in human cervical cancer. Cancer Res. 2007 Jul 1;67(13):6031-43. [Medline: 17616659] [doi: 10.1158/0008-5472.CAN-06-0561] [FREE Full Text]

40. Asangani IA, Rasheed SA, Nikolova DA, Leupold JH, Colburn NH, Post S, Allgayer H. MicroRNA-21 (miR-21) posttranscriptionally downregulates tumor suppressor Pdcd4 and stimulates invasion, intravasation and metastasis in colorectal cancer. Oncogene. 2008 Apr 3;27(15):2128-36. Epub 2007 Oct 29. [Medline: 17968323] [doi: 10.1038/sj.onc.1210856]

41. Meng F, Henson R, Wehbe-Janek H, Ghoshal K, Jacob ST, Patel T. MicroRNA-21 regulates expression of the PTEN tumor suppressor gene in human hepatocellular cancer. Gastroenterology. 2007 Aug;133(2):647-58. Epub 2007 May 21. [Medline: 17681183] [doi: 10.1053/j.gastro.2007.05.022]

42. Chan JA, Krichevsky AM, Kosik KS. MicroRNA-21 is an antiapoptotic factor in human glioblastoma cells. Cancer Res. 2005 Jul 15;65(14):6029-33. [Medline: 16024602] [doi: 10.1158/0008-5472.CAN-05-0137] [FREE Full Text]

43. Hu Y, Correa AM, Hoque A, Guan B, Ye F, Huang J, Swisher SG, Wu TT, Ajani JA, Xu XC. Prognostic significance of differentially expressed miRNAs in esophageal cancer. Int J Cancer. 2011 Jan 1;128(1):132-43. [Medline: 20309880] [doi: 10.1002/ijc.25330] [FREE Full Text]

44. Reis PP, Tomenson M, Cervigne NK, Machado J, Jurisica I, Pintilie M, Sukhai MA, Perez-Ordonez B, Grénman R, Gilbert RW, Gullane PJ, Irish JC, Kamel-Reid S. Programmed cell death 4 loss increases tumor cell invasion and is regulated by miR-21 in oral squamous cell carcinoma. Mol Cancer. 2010 Sep 10;9:238. [Medline: 20831814] [doi: 10.1186/1476-4598-9-238] [FREE Full Text]

45. Hsu CM, Lin PM, Wang YM, Chen ZJ, Lin SF, Yang MY. Circulating miRNA is a novel marker for head and neck squamous cell carcinoma. Tumour Biol. 2012 Dec;33(6):1933-42. Epub 2012 Jul 19. [Medline: 22811001] [doi: $10.1007 / \mathrm{s} 13277-012-0454-8$ ]

46. Papagiannakopoulos T, Shapiro A, Kosik KS. MicroRNA-21 targets a network of key tumor-suppressive pathways in glioblastoma cells. Cancer Res. 2008 Oct 1;68(19):8164-72. [Medline: 18829576] [doi: 10.1158/0008-5472.CAN-08-1305] [FREE Full Text]

47. Thum T, Gross C, Fiedler J, Fischer T, Kissler S, Bussen M, Galuppo P, Just S, Rottbauer W, Frantz S, Castoldi M, Soutschek J, Koteliansky V, Rosenwald A, Basson MA, Licht JD, Pena JT, Rouhanifard SH, Muckenthaler MU, Tuschl T, Martin GR, Bauersachs J, Engelhardt S. MicroRNA-21 contributes to myocardial disease by stimulating MAP kinase signalling in fibroblasts. Nature. 2008 Dec 18;456(7224):980-4. Epub 2008 Nov 30. [Medline: 19043405] [doi: 10.1038/nature07511]

48. Sayed D, Rane S, Lypowy J, He M, Chen IY, Vashistha H, Yan L, Malhotra A, Vatner D, Abdellatif M. MicroRNA-21 targets Sprouty2 and promotes cellular outgrowths. Mol Biol Cell. 2008 Aug;19(8):3272-82. Epub 2008 May 28. [Medline: 18508928] [doi: 10.1091/mbc.E08-02-0159] [FREE Full Text]

49. Wickramasinghe NS, Manavalan TT, Dougherty SM, Riggs KA, Li Y, Klinge CM. Estradiol downregulates miR21 expression and increases miR-21 target gene expression in MCF-7 breast cancer cells. Nucleic Acids Res. 2009 May;37(8):2584-95. Epub 2009 Mar 5. [Medline: 19264808] [doi: 10.1093/nar/gkp117] [FREE Full Text] 
50. Gabriely G, Wurdinger T, Kesari S, Esau CC, Burchard J, Linsley PS, Krichevsky AM. MicroRNA 21 promotes glioma invasion by targeting matrix metalloproteinase regulators. Mol Cell Biol. 2008 Sep;28(17):5369-80. Epub 2008 Jun 30. [Medline: 18591254] [doi: 10.1128/MCB.00479-08] [FREE Full Text]

51. Hashimi ST, Fulcher JA, Chang MH, Gov L, Wang S, Lee B. MicroRNA profiling identifies miR-34a and miR-21 and their target genes JAG1 and WNT1 in the coordinate regulation of dendritic cell differentiation. Blood. 2009 Jul 9;114(2):404-14. Epub 2009 Apr 27. [Medline: 19398721] [doi: 10.1182/blood-2008-09-179150] [FREE Full Text]

52. Kim YJ, Hwang SJ, Bae YC, Jung JS. MiR-21 regulates adipogenic differentiation through the modulation of TGFbeta signaling in mesenchymal stem cells derived from human adipose tissue. Stem Cells. 2009 Dec;27(12):3093-102. [Medline: 19816956] [doi: 10.1002/stem.235] [ [FREE Full Text]

53. Zheng J, Xue H, Wang T, Jiang Y, Liu B, Li J, Liu Y, Wang W, Zhang B, Sun M. miR-21 downregulates the tumor suppressor P12 CDK2AP1 and stimulates cell proliferation and invasion. J Cell Biochem. 2011 Mar;112(3):872-80. [Medline: 21328460] [doi: $\underline{10.1002 / j \mathrm{jcb} .22995]}$

54. Yelamanchili SV, Chaudhuri AD, Chen LN, Xiong H, Fox HS. MicroRNA-21 dysregulates the expression of MEF2C in neurons in monkey and human SIV/HIV neurological disease. Cell Death Dis. 2010;1:e77. [Medline: 21170291] [doi: 10.1038/cddis.2010.56] [FREE Full Text]

55. Sabatel C, Malvaux L, Bovy N, Deroanne C, Lambert V, Gonzalez ML, Colige A, Rakic JM, Noël A, Martial JA, Struman I. MicroRNA-21 exhibits antiangiogenic function by targeting RhoB expression in endothelial cells. PLoS One. 2011 Feb 10;6(2):e16979. [Medline: 21347332] [doi: 10.1371/journal.pone.0016979] [FREE Full Text]

56. Valeri N, Gasparini P, Braconi C, Paone A, Lovat F, Fabbri M, Sumani KM, Alder H, Amadori D, Patel T, Nuovo GJ, Fishel R, Croce CM. MicroRNA-21 induces resistance to 5-fluorouracil by down-regulating human DNA MutS homolog 2 (hMSH2). Proc Natl Acad Sci U S A. 2010 Dec 7;107(49):21098-103. [Medline: 21078976] [doi: 10.1073/pnas.1015541107]

57. Zhang X, Ng WL, Wang P, Tian L, Werner E, Wang H, Doetsch P, Wang Y. MicroRNA-21 modulates the levels of reactive oxygen species by targeting SOD3 and TNF $\alpha$. Cancer Res. 2012 Sep 15;72(18):4707-13. Epub 2012 Jul 25. [Medline: 22836756] [doi: 10.1158/0008-5472.CAN-12-0639] [FREE Full Text]

58. Tong AW, Nemunaitis J. Modulation of miRNA activity in human cancer: a new paradigm for cancer gene therapy? Cancer Gene Ther. 2008 Jun;15(6):341-55. Epub 2008 Mar 28. Review. [Medline: 18369380] [doi: 10.1038/cgt.2008.8]

59. Kong W, Yang H, He L, Zhao JJ, Coppola D, Dalton WS, Cheng JQ. MicroRNA-155 is regulated by the transforming growth factor beta/Smad pathway and contributes to epithelial cell plasticity by targeting RhoA. Mol Cell Biol. 2008 Nov;28(22):6773-84. [Medline: 18794355] [doi: 10.1128/MCB.00941-08] [FREE Full Text]

60. Kong W, Zhao JJ, He L, Cheng JQ. Strategies for profiling microRNA expression. J Cell Physiol. 2009 Jan;218(1):22-5. [Medline: 18767038] [doi: 10.1002/jcp.21577]

61. Jiang S, Zhang HW, Lu MH, He XH, Li Y, Gu H, Liu MF, Wang ED. MicroRNA-155 functions as an OncomiR in breast cancer by targeting the suppressor of cytokine signaling 1 gene. Cancer Res. 2010 Apr 15;70(8):3119-27. Epub 2010 Mar 30. [Medline: 20354188] [doi: 10.1158/0008-5472.CAN-09-4250] [FREE Full Text]

62. Lawrie CH. MicroRNAs and haematology: small molecules, big function. Br J Haematol. 2007 Jun;137(6):503-12. Review. [Medline: 17539773] [doi: 10.1111/j.1365-2141.2007.06611.x]

63. Kluiver J, Haralambieva E, de Jong D, Blokzijl T, Jacobs S, Kroesen BJ, Poppema S, van den Berg A. Lack of BIC and microRNA miR-155 expression in primary cases of Burkitt lymphoma. Genes Chromosomes Cancer. 2006 Feb;45(2):14753. [Medline: 16235244$]$ [doi: $10.1002 /$ gcc.20273]

64. Nikiforova MN, Tseng GC, Steward D, Diorio D, Nikiforov YE. MicroRNA expression profiling of thyroid tumors: biological significance and diagnostic utility. J Clin Endocrinol Metab. 2008 May;93(5):1600-8. Epub 2008 Feb 12. [Medline: 18270258] [doi: 10.1210/jc.2007-2696] [FREE Full Text]

65. Wang X, Tang S, Le SY, Lu R, Rader JS, Meyers C, Zheng ZM. Aberrant expression of oncogenic and tumor-suppressive microRNAs in cervical cancer is required for cancer cell growth. PLoS One. 2008 Jul 2;3(7):e2557. [Medline: 18596939] [doi: 10.1371/journal.pone.0002557] [ [FREE Full Text]

66. Lee EJ, Gusev Y, Jiang J, Nuovo GJ, Lerner MR, Frankel WL, Morgan DL, Postier RG, Brackett DJ, Schmittgen TD. Expression profiling identifies microRNA signature in pancreatic cancer. Int J Cancer. 2007 Mar 1;120(5):1046-54. [Medline: 17149698] [doi: 10.1002/ijc.22394] [FREE Full Text]

67. Szafranska AE, Davison TS, John J, Cannon T, Sipos B, Maghnouj A, Labourier E, Hahn SA. MicroRNA expression alterations are linked to tumorigenesis and non-neoplastic processes in pancreatic ductal adenocarcinoma. Oncogene. 2007 Jun 28;26(30):4442-52. Epub 2007 Jan 22. [Medline: 17237814] [doi: 10.1038/sj.onc.1210228]

68. Yanaihara N, Caplen N, Bowman E, Seike M, Kumamoto K, Yi M, Stephens RM, Okamoto A, Yokota J, Tanaka T, Calin GA, Liu CG, Croce CM, Harris CC. Unique microRNA molecular profiles in lung cancer diagnosis and prognosis. Cancer Cell. 2006 Mar;9(3):189-98. [Medline: 16530703] [doi: 10.1016/j.ccr.2006.01.025]

69. Roa W, Brunet B, Guo L, Amanie J, Fairchild A, Gabos Z, Nijjar T, Scrimger R, Yee D, Xing J. Identification of a new microRNA expression profile as a potential cancer screening tool. Clin Invest Med. 2010 Apr 1;33(2):E124. [Medline: 20370992] 
70. Liang Z, Wu H, Reddy S, Zhu A, Wang S, Blevins D, Yoon Y, Zhang Y, Shim H. Blockade of invasion and metastasis of breast cancer cells via targeting CXCR4 with an artificial microRNA. Biochem Biophys Res Commun. 2007 Nov 23;363(3):542-6. Epub 2007 Sep 14. [Medline: 17889832] [doi: 10.1016/j.bbrc.2007.09.007]

71. Wong DT. TGF-alpha and oral carcinogenesis. Eur J Cancer B Oral Oncol. 1993 Jan;29B(1):3-7. Review. [Medline: 8180574] [doi: 10.1016/0964-1955(93)90003-W]

72. Ovcharenko D, Kelnar K, Johnson C, Leng N, Brown D. Genome-scale microRNA and small interfering RNA screens identify small RNA modulators of TRAIL-induced apoptosis pathway. Cancer Res. 2007 Nov 15;67(22):10782-8. [Medline: 18006822] [doi: 10.1158/0008-5472.CAN-07-1484] [FREE Full Text]

73. Gironella M, Seux M, Xie MJ, Cano C, Tomasini R, Gommeaux J, Garcia S, Nowak J, Yeung ML, Jeang KT, Chaix A, Fazli L, Motoo Y, Wang Q, Rocchi P, Russo A, Gleave M, Dagorn JC, Iovanna JL, Carrier A, Pébusque MJ, Dusetti NJ. Tumor protein 53-induced nuclear protein 1 expression is repressed by miR-155, and its restoration inhibits pancreatic tumor development. Proc Natl Acad Sci U S A. 2007 Oct 9;104(41):16170-5. Epub 2007 Oct 2. [Medline: 17911264] [doi: 10.1073/pnas.0703942104] [FREE Full Text]

74. Faraoni I, Antonetti FR, Cardone J, Bonmassar E. miR-155 gene: a typical multifunctional microRNA. Biochim Biophys Acta. 2009 Jun;1792(6):497-505. Epub 2009 Mar 5. Review. [Medline: 19268705] [doi: 10.1016/j.bbadis.2009.02.013]

75. Teng G, Papavasiliou FN. Shhh! Silencing by microRNA-155. Philos Trans R Soc Lond B Biol Sci. 2009 Mar 12;364(1517):631-7. Review. [Medline: 19008191] [doi: 10.1098/rstb.2008.0209] [FREE Full Text]

76. Vigorito E, Perks KL, Abreu-Goodger C, Bunting S, Xiang Z, Kohlhaas S, Das PP, Miska EA, Rodriguez A, Bradley A, Smith KG, Rada C, Enright AJ, Toellner KM, Maclennan IC, Turner M. microRNA-155 regulates the generation of immunoglobulin class-switched plasma cells. Immunity. 2007 Dec;27(6):847-59. Epub 2007 Dec 6. [Medline: 18055230] [doi: 10.1016/j.immuni.2007.10.009]

77. Ma S, Tang KH, Chan YP, Lee TK, Kwan PS, Castilho A, Ng I, Man K, Wong N, To KF, Zheng BJ, Lai PB, Lo CM, Chan KW, Guan XY. miR-130b Promotes CD133(+) liver tumor-initiating cell growth and self-renewal via tumor protein 53-induced nuclear protein 1. Cell Stem Cell. 2010 Dec 3;7(6):694-707. [Medline: 21112564] [doi: $10.1016 /$ j.stem.2010.11.010]

78. Lai KW, Koh KX, Loh M, Tada K, Subramaniam MM, Lim XY, Vaithilingam A, Salto-Tellez M, Iacopetta B, Ito Y, Soong R; Singapore Gastric Cancer Consortium. MicroRNA-130b regulates the tumour suppressor RUNX3 in gastric cancer. Eur J Cancer. 2010 May;46(8):1456-63. Epub 2010 Feb 20. [Medline: 20176475] [doi: 10.1016/j.ejca.2010.01.036]

79. Wu X, Weng L, Li X, Guo C, Pal SK, Jin JM, Li Y, Nelson RA, Mu B, Onami SH, Wu JJ, Ruel NH, Wilczynski SP, Gao H, Covarrubias M, Figlin RA, Weiss LM, Wu H. Identification of a 4-microRNA signature for clear cell renal cell carcinoma metastasis and prognosis. PLoS One. 2012;7(5):e35661. Epub 2012 May 18. [Medline: 22623952] [doi: 10.1371/journal.pone.0035661] [FREE Full Text]

80. Rivetti di Val Cervo P, Lena AM, Nicoloso M, Rossi S, Mancini M, Zhou H, Saintigny G, Dellambra E, Odorisio T, Mahé C, Calin GA, Candi E, Melino G. p63-microRNA feedback in keratinocyte senescence. Proc Natl Acad Sci U S A. 2012 Jan 24;109(4):1133-8. Epub 2012 Jan 6. [Medline: 22228303] [doi: 10.1073/pnas.1112257109] [FREE Full Text]

81. Borgdorff V, Lleonart ME, Bishop CL, Fessart D, Bergin AH, Overhoff MG, Beach DH. Multiple microRNAs rescue from Ras-induced senescence by inhibiting p21(Waf1/Cip1). Oncogene. 2010 Apr 15;29(15):2262-71. Epub 2010 Jan 25. [Medline: 20101223] [doi: 10.1038/onc.2009.497]

82. Yeung ML, Yasunaga J, Bennasser Y, Dusetti N, Harris D, Ahmad N, Matsuoka M, Jeang KT. Roles for microRNAs, miR-93 and miR-130b, and tumor protein 53-induced nuclear protein 1 tumor suppressor in cell growth dysregulation by human T-cell lymphotrophic virus 1. Cancer Res. 2008 Nov 1;68(21):8976-85. [Medline: 18974142] [doi: 10.1158/0008-5472.CAN-08-0769] [ [FREE Full Text]

83. Dai Y, Xie CH, Neis JP, Fan CY, Vural E, Spring PM. MicroRNA expression profiles of head and neck squamous cell carcinoma with docetaxel-induced multidrug resistance. Head Neck. 2011 Jun;33(6):786-91. Epub 2010 Nov 29. [Medline: 21560177] [doi: 10.1002/hed.21540]

84. Sun W, Shen W, Yang S, Hu F, Li H, Zhu TH. miR-223 and miR-142 attenuatehematopoietic cell proliferation, and miR223 positively regulates miR-142 through LMO2 isoforms and CEBP- $\beta$. Cell Res. 2010 Oct;20(10):1158-69. Epub 2010 Sep 21. [Medline: 20856265] [doi: 10.1038/cr.2010.134]

85. Johnnidis JB, Harris MH, Wheeler RT, Stehling-Sun S, Lam MH, Kirak O, Brummelkamp TR, Fleming MD, Camargo FD. Regulation of progenitor cell proliferation and granulocyte function by microRNA-223. Nature. 2008 Feb 28;451(7182):1125-9. Epub 2008 Feb 17. [Medline: 18278031] [doi: 10.1038/nature06607]

86. Stamatopoulos B, Meuleman N, Haibe-Kains B, Saussoy P, Van Den Neste E, Michaux L, Heimann P, Martiat P, Bron D, Lagneaux L. microRNA-29c and microRNA-223 down-regulation has in vivo significance in chronic lymphocytic leukemia and improves disease risk stratification. Blood. 2009 May 21;113(21):5237-45. Epub 2009 Jan 14. [Medline: 19144983] [doi: 10.1182/blood-2008-11-189407] [FREE Full Text]

87. Chiaretti S, Messina M, Tavolaro S, Zardo G, Elia L, Vitale A, Fatica A, Gorello P, Piciocchi A, Scappucci G, Bozzoni I, Fozza C, Candoni A, Guarini A, Foà R. Gene expression profiling identifies a subset of adult T-cell acute lymphoblastic leukemia with myeloid-like gene features and over-expression of miR-223. Haematologica. 2010 Jul;95(7):1114-21. Epub 2010 Apr 23. [Medline: 20418243] [doi: 10.3324/haematol.2009.015099] [FREE Full Text] 
88. Eyholzer M, Schmid S, Schardt JA, Haefliger S, Mueller BU, Pabst T. Complexity of miR-223 regulation by CEBPA in human AML. Leuk Res. 2010 May;34(5):672-6. Epub 2009 Dec 16. [Medline: 20018373] [doi: 10.1016/j.leukres.2009.11.019]

89. Pulikkan JA, Dengler V, Peramangalam PS, Peer Zada AA, Müller-Tidow C, Bohlander SK, Tenen DG, Behre G. Cellcycle regulator E2F1 and microRNA-223 comprise an autoregulatory negative feedback loop in acute myeloid leukemia. Blood. 2010 Mar 4;115(9):1768-78. Epub 2009 Dec 22. [Medline: 20029046] [doi: 10.1182/blood-2009-08-240101] [FREE Full Text]

90. Kurashige J, Watanabe M, Iwatsuki M, Kinoshita K, Saito S, Hiyoshi Y, Kamohara H, Baba Y, Mimori K, Baba H. Overexpression of microRNA-223 regulates the ubiquitin ligase FBXW7 in oesophageal squamous cell carcinoma. Br J Cancer. 2012 Jan 3;106(1):182-8. Epub 2011 Nov 22. [Medline: 22108521] [doi: 10.1038/bjc.2011.509] [FREE Full Text]

91. Li J, Guo Y, Liang X, Sun M, Wang G, De W, Wu W. MicroRNA-223 functions as an oncogene in human gastric cancer by targeting FBXW7/hCdc4. J Cancer Res Clin Oncol. 2012 May;138(5):763-74. Epub 2012 Jan 22. [Medline: 22270966] [doi: 10.1007/s00432-012-1154-x]

92. Li X, Zhang Y, Zhang H, Liu X, Gong T, Li M, Sun L, Ji G, Shi Y, Han Z, Han S, Nie Y, Chen X, Zhao Q, Ding J, Wu K, Daiming F. miRNA-223 promotes gastric cancer invasion and metastasis by targeting tumor suppressor EPB41L3. Mol Cancer Res. 2011 Jul;9(7):824-33. Epub 2011 May 31. [Medline: 21628394] [doi: 10.1158/1541-7786.MCR-10-0529] [FREE Full Text]

93. Xu J, Wu C, Che X, Wang L, Yu D, Zhang T, Huang L, Li H, Tan W, Wang C, Lin D. Circulating microRNAs, miR-21, miR-122, and miR-223, in patients with hepatocellular carcinoma or chronic hepatitis. Mol Carcinog. 2011 Feb;50(2):13642. Epub 2010 Dec 10. [Medline: 21229610] [doi: 10.1002/mc.20712]

94. Liu CJ, Kao SY, Tu HF, Tsai MM, Chang KW, Lin SC. Increase of microRNA miR-31 level in plasma could be a potential marker of oral cancer. Oral Dis. 2010 May;16(4):360-4. Epub 2010 Mar 9. [Medline: 20233326] [doi: 10.1111/j.1601-0825.2009.01646.x]

95. Bandrés E, Cubedo E, Agirre X, Malumbres R, Zárate R, Ramirez N, Abajo A, Navarro A, Moreno I, Monzó M, García-Foncillas J. Identification by Real-time PCR of 13 mature microRNAs differentially expressed in colorectal cancer and non-tumoral tissues. Mol Cancer. 2006 Jul 19;5:29. [Medline: 16854228] [doi: 10.1186/1476-4598-5-29] [FREE Full Text]

96. Slaby O, Svoboda M, Fabian P, Smerdova T, Knoflickova D, Bednarikova M, Nenutil R, Vyzula R. Altered expression of miR-21, miR-31, miR-143 and miR-145 is related to clinicopathologic features of colorectal cancer. Oncology. 2007;72(56):397-402. [Medline: 18196926] [doi: 10.1159/000113489]

97. Wong QW, Lung RW, Law PT, Lai PB, Chan KY, To KF, Wong N. MicroRNA-223 is commonly repressed in hepatocellular carcinoma and potentiates expression of Stathmin1. Gastroenterology. 2008 Jul;135(1):257-69. Epub 2008 Apr 11. [Medline: 18555017] [doi: 10.1053/j.gastro.2008.04.003]

98. Yan LX, Huang XF, Shao Q, Huang MY, Deng L, Wu QL, Zeng YX, Shao JY. MicroRNA miR-21 overexpression in human breast cancer is associated with advanced clinical stage, lymph node metastasis and patient poor prognosis. RNA. 2008 Nov;14(11):2348-60. Epub 2008 Sep 23. [Medline: 18812439] [doi: 10.1261/rna.1034808] [FREE Full Text]

99. Veerla S, Lindgren D, Kvist A, Frigyesi A, Staaf J, Persson H, Liedberg F, Chebil G, Gudjonsson S, Borg A, Månsson W, Rovira C, Höglund M. MiRNA expression in urothelial carcinomas: important roles of miR-10a, miR-222, miR125b, miR-7 and miR-452 for tumor stage and metastasis, and frequent homozygous losses of miR-31. Int J Cancer. 2009 May 1;124(9):2236-42. [Medline: 19127597] [doi: 10.1002/ijc.24183]

100. Valastyan S, Reinhardt F, Benaich N, Calogrias D, Szász AM, Wang ZC, Brock JE, Richardson AL, Weinberg RA. A pleiotropically acting microRNA, miR-31, inhibits breast cancer metastasis. Cell. 2009 Jun 12;137(6):1032-46. [Medline: 19524507] [doi: 10.1016/j.cell.2009.03.047] [FREE Full Text]

101. Cottonham CL, Kaneko S, Xu L. miR-21 and miR-31 converge on TIAM1 to regulate migration and invasion of colon carcinoma cells. J Biol Chem. 2010 Nov 2;285(46):35293-302. Epub 2010 Sep 7. [Medline: 20826792] [doi: 10.1074/jbc.M110.160069] [FREE Full Text]

102.Laurila EM, Sandström S, Rantanen LM, Autio R, Kallioniemi A. Both inhibition and enhanced expression of miR-31 lead to reduced migration and invasion of pancreatic cancer cells. Genes Chromosomes Cancer. 2012 Jun;51(6):557-68. Epub 2012 Feb 16. [Medline: 22344632] [doi: 10.1002/gcc.21941]

103. Rentoft M, Fahlén J, Coates PJ, Laurell G, Sjöström B, Rydén P, Nylander K. miRNA analysis of formalin-fixed squamous cell carcinomas of the tongue is affected by age of the samples. Int J Oncol. 2011 Jan;38(1):61-9. [Medline: 21109926]

104.Ramdas L, Giri U, Ashorn CL, Coombes KR, El-Naggar A, Ang KK, Story MD. miRNA expression profiles in head and neck squamous cell carcinoma and adjacent normal tissue. Head Neck. 2009 May;31(5):642-54. [Medline: 19260130] [doi: 10.1002/hed.21017] [ [FREE Full Text]

105.Kefas B, Godlewski J, Comeau L, Li Y, Abounader R, Hawkinson M, Lee J, Fine H, Chiocca EA, Lawler S, Purow B. microRNA-7 inhibits the epidermal growth factor receptor and the Akt pathway and is down-regulated in glioblastoma. Cancer Res. 2008 May 15;68(10):3566-72. [Medline: 18483236] [doi: 10.1158/0008-5472.CAN-07-6639] [FREE Full Text] 
106. Webster RJ, Giles KM, Price KJ, Zhang PM, Mattick JS, Leedman PJ. Regulation of epidermal growth factor receptor signaling in human cancer cells by microRNA-7. J Biol Chem. 2009 Feb 27;284(9):5731-41. Epub 2008 Dec 10. [Medline: 19073608] [doi: 10.1074/jbc.M804280200] [FREE Full Text]

107. Reddy SD, Ohshiro K, Rayala SK, Kumar R. MicroRNA-7, a homeobox D10 target, inhibits p21-activated kinase 1 and regulates its functions. Cancer Res. 2008 Oct 15;68(20):8195-200. [Medline: 18922890] [doi: 10.1158/0008-5472.CAN-08-2103] [FREE Full Text]

108.Liu X, Jiang L, Wang A, Yu J, Shi F, Zhou X. MicroRNA-138 suppresses invasion and promotes apoptosis in head and neck squamous cell carcinoma cell lines. Cancer Lett. 2009 Dec 28;286(2):217-22. Epub 2009 Jun 21. [Medline: 19540661] [doi: 10.1016/j.canlet.2009.05.030] [FREE Full Text]

109.Liu X, Yu J, Jiang L, Wang A, Shi F, Ye H, Zhou X. MicroRNA-222 regulates cell invasion by targeting matrix metalloproteinase 1 (MMP1) and manganese superoxide dismutase 2 (SOD2) in tongue squamous cell carcinoma cell lines. Cancer Genomics Proteomics. 2009 May-Jun;6(3):131-9. [Medline: 19487542] [FREE Full Text]

110.Jiang L, Liu X, Chen Z, Jin Y, Heidbreder CE, Kolokythas A, Wang A, Dai Y, Zhou X. MicroRNA-7 targets IGF1R (insulin-like growth factor 1 receptor) in tongue squamous cell carcinoma cells. Biochem J. 2010 Nov 15;432(1):199-205. [Medline: 20819078] [doi: 10.1042/BJ20100859] [FREE Full Text]

111. Jung HM, Phillips BL, Patel RS, Cohen DM, Jakymiw A, Kong WW, Cheng JQ, Chan EK. Keratinizationassociated miR-7 and miR-21 regulate tumor suppressor reversion-inducing cysteine-rich protein with kazal motifs (RECK) in oral cancer. J Biol Chem. 2012 Aug 24;287(35):29261-72. Epub 2012 Jul 2. [Medline: 22761427] [doi: 10.1074/jbc.M112.366518] [FREE Full Text]

112. Toyota M, Suzuki H, Sasaki Y, Maruyama R, Imai K, Shinomura Y, Tokino T. Epigenetic silencing of microRNA$34 \mathrm{~b} / \mathrm{c}$ and B-cell translocation gene 4 is associated with $\mathrm{CpG}$ island methylation in colorectal cancer. Cancer Res. 2008 Jun 1;68(11):4123-32. [Medline: 18519671] [doi: 10.1158/0008-5472.CAN-08-0325] [FREE Full Text]

113. Rokhlin OW, Scheinker VS, Taghiyev AF, Bumcrot D, Glover RA, Cohen MB. MicroRNA-34 mediates ARdependent p53-induced apoptosis in prostate cancer. Cancer Biol Ther. 2008 Aug;7(8):1288-96. Epub 2008 Aug 13. [Medline: 18497571] [doi: 10.4161/cbt.7.8.6284] [FREE Full Text]

114.Ji Q, Hao X, Meng Y, Zhang M, Desano J, Fan D, Xu L. Restoration of tumor suppressor miR-34 inhibits human p53-mutant gastric cancer tumorspheres. BMC Cancer. 2008 Sep 21;8:266. [Medline: 18803879] [doi: 10.1186/1471-2407-8-266] [FREE Full Text]

115. Lee YM, Lee JY, Ho CC, Hong QS, Yu SL, Tzeng CR, Yang PC, Chen HW. miRNA-34b as a tumor suppressor in estrogen-dependent growth of breast cancer cells. Breast Cancer Res. 2011;13(6):R116. Epub 2011 Nov 23. [Medline: 22113133] [doi: 10.1186/bcr3059] [FREE Full Text]

116. Siemens H, Jackstadt R, Hünten S, Kaller M, Menssen A, Götz U, Hermeking H. miR-34 and SNAIL form a doublenegative feedback loop to regulate epithelial-mesenchymal transitions. Cell Cycle. 2011 Dec 15;10(24):4256-71. Epub 2011 Dec 15. [Medline: 22134354] [doi: 10.4161/cc.10.24.18552]

117. Kozaki K, Imoto I, Mogi S, Omura K, Inazawa J. Exploration of tumor-suppressive microRNAs silenced by DNA hypermethylation in oral cancer. Cancer Res. 2008 Apr 1;68(7):2094-105. [Medline: 18381414] [doi: 10.1158/0008-5472.CAN-07-5194]

118. Chen X, Hu H, Guan X, Xiong G, Wang Y, Wang K, Li J, Xu X, Yang K, Bai Y. CpG island methylation status of miRNAs in esophageal squamous cell carcinoma. Int J Cancer. 2012 Apr 1;130(7):1607-13. Epub 2011 Aug 24. [Medline: 21547903] [doi: 10.1002/ijc.26171]

119. Wang Z, Chen Z, Gao Y, Li N, Li B, Tan F, Tan X, Lu N, Sun Y, Sun J, Sun N, He J. DNA hypermethylation of microRNA-34b/c has prognostic value for stage I non-small cell lung cancer. Cancer Biol Ther. 2011 Mar 1;11(5):490-6. [Medline: 21383543] [doi: 10.4161/cbt.11.5.14550] [FREE Full Text]

120.Corney DC, Flesken-Nikitin A, Godwin AK, Wang W, Nikitin AY. MicroRNA-34b and MicroRNA-34c are targets of p53 and cooperate in control of cell proliferation and adhesion-independent growth. Cancer Res. 2007 Sep 15;67(18):8433-8. Epub 2007 Sep 6. [Medline: 17823410] [doi: 10.1158/0008-5472.CAN-07-1585] [FREE Full Text]

121.He L, He X, Lim LP, de Stanchina E, Xuan Z, Liang Y, Xue W, Zender L, Magnus J, Ridzon D, Jackson AL, Linsley PS, Chen C, Lowe SW, Cleary MA, Hannon GJ. A microRNA component of the p53 tumour suppressor network. Nature. 2007 Jun 28;447(7148):1130-4. Epub 2007 Jun 6. [Medline: 17554337] [10.1038/nature05939]

122.He L, He X, Lowe SW, Hannon GJ. microRNAs join the p53 network--another piece in the tumour-suppression puzzle. Nat Rev Cancer. 2007 Nov;7(11):819-22. Review. [Medline: 17914404] [doi: 10.1038/nrc2232]

123. Wang LG, Ni Y, Su BH, Mu XR, Shen HC, Du JJ. MicroRNA-34b functions as a tumor suppressor and acts as a nodal point in the feedback loop with Met. Int J Oncol. 2013 Mar;42(3):957-62. Epub 2013 Jan 10. [Medline: 23314612]

124. Hertel J, Bartschat S, Wintsche A, Otto C; Students of the Bioinformatics Computer Lab, Stadler PF. Evolution of the let-7 microRNA family. RNA Biol. 2012 Mar;9(3):231-41. Epub 2012 Mar 1. [Medline: 22617875] [doi: 10.4161/rna.18974] [FREE Full Text]

125. Heimberg AM, Sempere LF, Moy VN, Donoghue PC, Peterson KJ. MicroRNAs and the advent of vertebrate morphological complexity. Proc Natl Acad Sci U S A. 2008 Feb 26;105(8):2946-50. Epub 2008 Feb 14. [Medline: 18287013] [doi: 10.1073/pnas.0712259105] [ [FREE Full Text] 
126. Sun D, Lee YS, Malhotra A, Kim HK, Matecic M, Evans C, Jensen RV, Moskaluk CA, Dutta A. miR-99 family of MicroRNAs suppresses the expression of prostate-specific antigen and prostate cancer cell proliferation. Cancer Res. 2011 Feb 15;71(4):1313-24. Epub 2011 Jan 6. [Medline: 21212412] [doi: 10.1158/0008-5472.CAN-10-1031] [FREE Full Text]

127.Li BH, Zhou JS, Ye F, Cheng XD, Zhou CY, Lu WG, Xie X. Reduced miR-100 expression in cervical cancer and precursors and its carcinogenic effect through targeting PLK1 protein. Eur J Cancer. 2011 Sep;47(14):2166-74. [Medline: 21636267] [doi: 10.1016/j.ejca.2011.04.037]

128. Cairo S, Wang Y, de Reyniès A, Duroure K, Dahan J, Redon MJ, Fabre M, McClelland M, Wang XW, Croce CM, Buendia MA. Stem cell-like micro-RNA signature driven by Myc in aggressive liver cancer. Proc Natl Acad Sci U S A. 2010 Nov 23;107(47):20471-6. Epub 2010 Nov 8. [Medline: 21059911] [doi: 10.1073/pnas.1009009107] [FREE Full Text]

129.Henson BJ, Bhattacharjee S, O’Dee DM, Feingold E, Gollin SM. Decreased expression of miR-125b and miR-100 in oral cancer cells contributes to malignancy. Genes Chromosomes Cancer. 2009 Jul;48(7):569-82. [Medline: 19396866] [doi: 10.1002/gcc.20666] [FREE Full Text]

130.Peng DX, Luo M, Qiu LW, He YL, Wang XF. Prognostic implications of microRNA-100 and its functional roles in human epithelial ovarian cancer. Oncol Rep. 2012 Apr;27(4):1238-44. Epub 2012 Jan 11. [Medline: 22246341] [doi: 10.3892/or.2012.1625] [FREE Full Text]

131.Petrelli A, Perra A, Schernhuber K, Cargnelutti M, Salvi A, Migliore C, Ghiso E, Benetti A, Barlati S, Ledda-Columbano GM, Portolani N, De Petro G, Columbano A, Giordano S. Sequential analysis of multistage hepatocarcinogenesis reveals that miR-100 and PLK1 dysregulation is an early event maintained along tumor progression. Oncogene. 2012 Oct 18;31(42):4517-26. Epub 2012 Jan 16. [Medline: 22249248] [doi: 10.1038/onc.2011.631]

132. Kinoshita T, Nohata N, Yoshino H, Hanazawa T, Kikkawa N, Fujimura L, Chiyomaru T, Kawakami K, Enokida H, Nakagawa M, Okamoto Y, Seki N. Tumor suppressive microRNA-375 regulates lactate dehydrogenase B in maxillary sinus squamous cell carcinoma.Int J Oncol. 2012 Jan;40(1):185-93. Epub 2011 Sep 12. [Medline: 21922130] [doi: 10.3892/ijo.2011.1196]

133. Nagaraja AK, Creighton CJ, Yu Z, Zhu H, Gunaratne PH, Reid JG, Olokpa E, Itamochi H, Ueno NT, Hawkins SM, Anderson ML, Matzuk MM. A link between mir-100 and FRAP1/mTOR in clear cell ovarian cancer. Mol Endocrinol. 2010 Feb;24(2):447-63. Epub 2010 Jan 15. [Medline: 20081105] [doi: 10.1210/me.2009-0295] [FREE Full Text]

134. Tovar V, Alsinet C, Villanueva A, Hoshida Y, Chiang DY, Solé M, Thung S, Moyano S, Toffanin S, Mínguez B, Cabellos L, Peix J, Schwartz M, Mazzaferro V, Bruix J, Llovet JM. IGF activation in a molecular subclass of hepatocellular carcinoma and pre-clinical efficacy of IGF-1R blockage. J Hepatol. 2010 Apr;52(4):550-9. Epub 2010 Feb 13. [Medline: 20206398] [doi: 10.1016/j.jhep.2010.01.015]

135.Doghman M, El Wakil A, Cardinaud B, Thomas E, Wang J, Zhao W, Peralta-Del Valle MH, Figueiredo BC, Zambetti GP, Lalli E. Regulation of insulin-like growth factor-mammalian target of rapamycin signaling by microRNA in childhood adrenocortical tumors. Cancer Res. 2010 Jun 1;70(11):4666-75. Epub 2010 May 18. [Medline: 20484036] [doi: 10.1158/0008-5472.CAN-09-3970] [FREE Full Text]

136. Chen Z, Jin Y, Yu D, Wang A, Mahjabeen I, Wang C, Liu X, Zhou X. Down-regulation of the microRNA-99 family members in head and neck squamous cell carcinoma. Oral Oncol. 2012 Aug;48(8):686-91. Epub 2012 Mar 17. [Medline: 22425712] [doi: 10.1016/j.oraloncology.2012.02.020]

137. Mueller AC, Sun D, Dutta A. The miR-99 family regulates the DNA damage response through its target SNF2H. Oncogene. 2013 Feb 28;32(9):1164-72. Epub 2012 Apr 23. [Medline: 22525276] [doi: 10.1038/onc.2012.131] [ [FREE Full Text]

138. Wiklund ED, Gao S, Hulf T, Sibbritt T, Nair S, Costea DE, Villadsen SB, Bakholdt V, Bramsen JB, Sørensen JA, Krogdahl A, Clark SJ, Kjems J. MicroRNA alterations and associated aberrant DNA methylation patterns across multiple sample types in oral squamous cell carcinoma. PLoS One. 2011;6(11):e27840. 2011 Nov 22. [Medline: 22132151] [FREE Full Text] [doi: 10.1371/journal.pone.0027840]

139.Ding L, Xu Y, Zhang W, Deng Y, Si M, Du Y, Yao H, Liu X, Ke Y, Si J, Zhou T. MiR-375 frequently downregulated in gastric cancer inhibits cell proliferation by targeting JAK2. Cell Res. 2010 Jul;20(7):784-93. Epub 2010 Jun 15. [Medline: 20548334] [doi: 10.1038/cr.2010.79]

140.Liu AM, Poon RT, Luk JM. MicroRNA-375 targets Hippo-signaling effector YAP in liver cancer and inhibits tumor properties. Biochem Biophys Res Commun. 2010 Apr 9;394(3):623-7. Epub 2010 Mar 10. [Medline: 20226166] [doi: 10.1016/j.bbrc.2010.03.036]

141.de Souza Rocha Simonini P, Breiling A, Gupta N, Malekpour M, Youns M, Omranipour R, Malekpour F, Volinia S, Croce CM, Najmabadi H, Diederichs S, Sahin O, Mayer D, Lyko F, Hoheisel JD, Riazalhosseini Y. Epigenetically deregulated microRNA-375 is involved in a positive feedback loop with estrogen receptor alpha in breast cancer cells. Cancer Res. 2010 Nov 15;70(22):9175-84. Epub 2010 Oct 26. [Medline: 20978187] [doi: 10.1158/0008-5472.CAN-10-1318] [FREE Full Text] 
142. Tsukamoto Y, Nakada C, Noguchi T, Tanigawa M, Nguyen LT, Uchida T, Hijiya N, Matsuura K, Fujioka T, Seto M, Moriyama M. MicroRNA-375 is downregulated in gastric carcinomas and regulates cell survival by targeting PDK1 and 14-3-3zeta. Cancer Res. 2010 Mar 15;70(6):2339-49. Epub 2010 Mar 9. [Medline: 20215506] [doi: 10.1158/0008-5472.CAN-09-2777] [FREE Full Text]

143. Nohata N, Hanazawa T, Kikkawa N, Mutallip M, Sakurai D, Fujimura L, Kawakami K, Chiyomaru T, Yoshino H, Enokida H, Nakagawa M, Okamoto Y, Seki N. Tumor suppressive microRNA-375 regulates oncogene AEG-1/MTDH in head and neck squamous cell carcinoma (HNSCC). J Hum Genet. 2011 Aug;56(8):595-601. Epub 2011 Jul 14. [Medline: 21753766] [doi: 10.1038/jhg.2011.66]

144.Li X, Lin R, Li J. Epigenetic silencing of microRNA-375 regulates PDK1expression in esophageal cancer. Dig Dis Sci. 2011 Oct;56(10):2849-56. Epub 2011 Apr 30. [Medline: 21533613] [doi: 10.1007/s10620-011-1711-1]

145. Yu T, Wang XY, Gong RG, Li A, Yang S, Cao YT, Wen YM, Wang CM, Yi XZ. The expression profile of microRNAs in a model of 7,12-dimethyl-benz[a] anthrance-induced oral carcinogenesis in Syrian hamster. J Exp Clin Cancer Res. 2009 May 13;28:64. [Medline: 19435529] [doi: 10.1186/1756-9966-28-64] [FREE Full Text]

146. Shang C, Lu YM, Meng LR. MicroRNA-125b down-regulation mediates endometrial cancer invasion by targeting ERBB2. Med Sci Monit. 2012 Apr;18(4):BR149-55. [Medline: 22460089] [doi: 10.12659/MSM.882617]

147.Xu N, Zhang L, Meisgen F, Harada M, Heilborn J, Homey B, Grandér D, Ståhle M, Sonkoly E, Pivarcsi A. MicroRNA125b down-regulates matrix metallopeptidase 13 and inhibits cutaneous squamous cell carcinoma cell proliferation, migration, and invasion. J Biol Chem. 2012 Aug 24;287(35):29899-908. Epub 2012 Jul 10. [Medline: 22782903] [doi: $10.1074 /$ jbc.M112.391243] [FREE Full Text]

148.Jiang L, Dai Y, Liu X, Wang C, Wang A, Chen Z, Heidbreder CE, Kolokythas A, Zhou X. Identification and experimental validation of $\mathrm{G}$ protein alpha inhibiting activity polypeptide 2 (GNAI2) as a microRNA-138 target in tongue squamous cell carcinoma. Hum Genet. 2011 Feb;129(2):189-97. Epub 2010 Nov 16. [Medline: 21079996] [doi: 10.1007/s00439-010-0915-3] [FREE Full Text]

149. Mitomo S, Maesawa C, Ogasawara S, Iwaya T, Shibazaki M, Yashima-Abo A, Kotani K, Oikawa H, Sakurai E, Izutsu N, Kato K, Komatsu H, Ikeda K, Wakabayashi G, Masuda T. Downregulation of miR-138 is associated with overexpression of human telomerase reverse transcriptase protein in human anaplastic thyroid carcinoma cell lines. Cancer Sci. 2008 Feb;99(2):280-6. Epub 2008 Jan 14. [Medline: 18201269] [doi: 10.1111/j.1349-7006.2007.00666.x]

150.Jiang L, Liu X, Kolokythas A, Yu J, Wang A, Heidbreder CE, Shi F, Zhou X. Downregulation of the Rho GTPase signaling pathway is involved in the microRNA-138-mediated inhibition of cell migration and invasion in tongue squamous cell carcinoma. Int J Cancer. 2010 Aug 1;127(3):505-12. [Medline: 20232393] [doi: 10.1002/ijc.25320] [FREE Full Text]

151. Gregory PA, Bert AG, Paterson EL, Barry SC, Tsykin A, Farshid G, Vadas MA, Khew-Goodall Y, Goodall GJ. The miR200 family and miR-205 regulate epithelial to mesenchymal transition by targeting ZEB1 and SIP1. Nat Cell Biol. 2008 May;10(5):593-601. Epub 2008 Mar 30. [Medline: 18376396] [doi: 10.1038/ncb1722]

152. Varambally S, Cao Q, Mani RS, Shankar S, Wang X, Ateeq B, Laxman B, Cao X, Jing X, Ramnarayanan K, Brenner JC, Yu J, Kim JH, Han B, Tan P, Kumar-Sinha C, Lonigro RJ, Palanisamy N, Maher CA, Chinnaiyan AM. Genomic loss of microRNA-101 leads to overexpression of histone methyltransferase EZH2 in cancer. Science. 2008 Dec 12;322(5908):1695-9. Epub 2008 Nov 13. [Medline: 19008416] [doi: 10.1126/science.1165395] [FREE Full Text]

153. Friedman JM, Liang G, Liu CC, Wolff EM, Tsai YC, Ye W, Zhou X, Jones PA. The putative tumor suppressor microRNA-101 modulates the cancer epigenome by repressing the polycomb group protein EZH2. Cancer Res. 2009 Mar 15;69(6):2623-9. Epub 2009 Mar 3. [Medline: 19258506] [doi: 10.1158/0008-5472.CAN-08-3114]

154. Cao Q, Yu J, Dhanasekaran SM, Kim JH, Mani RS, Tomlins SA, Mehra R, Laxman B, Cao X, Yu J, Kleer CG, Varambally $\mathrm{S}$, Chinnaiyan AM. Repression of E-cadherin by the polycomb group protein EZH2 in cancer. Oncogene. 2008 Dec 11;27(58):7274-84. Epub 2008 Sep 22. [Medline: 18806826] [doi: 10.1038/onc.2008.333] [FREE Full Text]

155.Hebert C, Norris K, Scheper MA, Nikitakis N, Sauk JJ. High mobility group A2 is a target for miRNA-98 in head and neck squamous cell carcinoma. Mol Cancer. 2007 Jan 14;6:5. [Medline: 17222355] [doi: 10.1186/1476-4598-6-5] [FREE Full Text]

156.Johnson SM, Grosshans H, Shingara J, Byrom M, Jarvis R, Cheng A, Labourier E, Reinert KL, Brown D, Slack FJ. RAS is regulated by the let-7 microRNA family. Cell. 2005 Mar 11;120(5):635-47. [Medline: 15766527] [doi: 10.1016/j.cell.2005.01.014]

157.Uesugi A, Kozaki K, Tsuruta T, Furuta M, Morita K, Imoto I, Omura K, Inazawa J. The tumor suppressive microRNA miR-218 targets the mTOR component Rictor and inhibits AKT phosphorylation in oral cancer. Cancer Res. 2011 Sep 1;71(17):5765-78. Epub 2011 Jul 27. [Medline: 21795477] [doi: 10.1158/0008-5472.CAN-11-0368] [FREE Full Text]

158. Silber J, Lim DA, Petritsch C, Persson AI, Maunakea AK, Yu M, Vandenberg SR, Ginzinger DG, James CD, Costello JF, Bergers G, Weiss WA, Alvarez-Buylla A, Hodgson JG. miR-124 and miR-137 inhibit proliferation of glioblastoma multiforme cells and induce differentiation of brain tumor stem cells. BMC Med. 2008 Jun 24;6:14. [Medline: 18577219] [doi: 10.1186/1741-7015-6-14] [ [FREE Full Text]

159. Bemis LT, Chen R, Amato CM, Classen EH, Robinson SE, Coffey DG, Erickson PF, Shellman YG, Robinson WA. MicroRNA-137 targets microphthalmia-associated transcription factor in melanoma cell lines. Cancer Res. 2008 Mar 1;68(5):1362-8. [Medline: 18316599] [doi: 10.1158/0008-5472.CAN-07-2912] [FREE Full Text] 
160.Döbrossy L. Epidemiology of head and neck cancer: magnitude of the problem. Cancer Metastasis Rev. 2005 Jan;24(1): 9-17. Review. [Medline: 15785869] [doi: 10.1007/s10555-005-5044-4]

161.Tímár J, Csuka O, Remenár E, Répássy G, Kásler M. Progression of head and neck squamous cell cancer. Cancer Metastasis Rev. 2005 Jan;24(1):107-27. Review. [Medline: 15785876] [doi: 10.1007/s10555-005-5051-5]

162. Shah JP, Patel SG. Results of treatment. In: Shah JP, Johnson NW, Batsakis JG, editors. Oral Cancer. London: Martin Dunitz; 2003. p. 387-94.

163.Zelefsky MJ, Harrison LB, Fass DE, Armstrong J, Spiro RH, Shah JP, Strong EW. Postoperative radiotherapy for oral cavity cancers: impact of anatomic subsite on treatment outcome. Head Neck. 1990 Nov-Dec;12(6):470-5. [Medline: 2258285] [doi: 10.1002/hed.2880120604]

\section{To cite this article:}

Chen D, Cabay RJ, Jin Y, Wang A, Luo Y, Shah-Khan M, Zhou X. MicroRNA Deregulations in Head and Neck Squamous Cell Carcinomas.

J Oral Maxillofac Res 2013;4(1):e2

URL: http://www.ejomr.org/JOMR/archives/2013/1/e2/v4n1e2ht.pdf

doi: $10.5037 /$ jomr.2013.4102

Copyright (C) Chen D, Cabay RJ, Jin Y, Wang A, Luo Y, Shah-Khan M, Zhou X. Accepted for publication in the JOURNAL OF ORAL \& MAXILLOFACIAL RESEARCH (http://www.ejomr.org), 4 March 2013.

This is an open-access article, first published in the JOURNAL OF ORAL \& MAXILLOFACIAL RESEARCH, distributed under the terms of the Creative Commons Attribution-Noncommercial-No Derivative Works 3.0 Unported License, which permits unrestricted non-commercial use, distribution, and reproduction in any medium, provided the original work and is properly cited. The copyright, license information and link to the original publication on (http://www.ejomr.org) must be included. 